University of Rhode Island

DigitalCommons@URI

Open Access Master's Theses

2012

\title{
The Indirect Effect of Earthworms on Methane Flux in two Temperate Pasture Soils
}

\author{
Edward J. Avizinis \\ University of Rhode Island, eddie@my.uri.edu
}

Follow this and additional works at: https://digitalcommons.uri.edu/theses

\section{Recommended Citation}

Avizinis, Edward J., "The Indirect Effect of Earthworms on Methane Flux in two Temperate Pasture Soils" (2012). Open Access Master's Theses. Paper 96.

https://digitalcommons.uri.edu/theses/96

This Thesis is brought to you for free and open access by DigitalCommons@URI. It has been accepted for inclusion in Open Access Master's Theses by an authorized administrator of DigitalCommons@URI. For more information, please contact digitalcommons-group@uri.edu. 
THE INDIRECT EFFECT OF EARTHWORMS ON

METHANE FLUX IN TWO TEMPERATE PASTURE SOILS

BY

EDWARD J. AVIZINIS

A DISSERTATION SUBMITTED IN PARTIAL FULFILLMENT OF THE

REQUIREMENTS FOR THE DEGREE OF

MASTER OF SCIENCE

IN

ENVIRONMENTAL SCIENCE

UNIVERSITY OF RHODE ISLAND

2012 


\title{
MASTER OF SCIENCE THESIS
}

$\mathrm{OF}$

\author{
EDWARD J. AVIZINIS
}

\section{APPROVED:}

Thesis Committee:

Major Professor José A. Amador, Ph.D.

Thomas Boving, Ph.D.

Mark H. Stolt, Ph.D.

Nasser H. Zawia

DEAN OF THE GRADUATE SCHOOL

UNIVERSITY OF RHODE ISLAND

2012 


\begin{abstract}
Methane, a potent greenhouse gas, is produced or consumed by microorganisms in soil, depending on soil conditions. In general, anaerobic conditions promote activity of methanogenic Archaea, whereas aerobic conditions promote methane consumption by methanotrophic bacteria. Earthworms may have an effect on methane flux in soil by altering soil pore space, aeration, moisture content, and organic carbon availability, all of which affect the activities of methanogens and methanotrophs. As the range of European and Asian earthworm species expands throughout the United States, their potential effects on methane flux may have global implications.
\end{abstract}

My research focused on the effects of earthworms on methane flux in temperate pastures and on the potential mechanisms involved. In November, 2009, I established 24 experimental plots each at Peckham Farm (PF), Kingston, and at the W. Alton Jones (WAJ) campus of the University of Rhode Island, West Greenwich, both in southern Rhode Island. Three treatments $(n=8)$ were implemented: (i) earthworms removed (D-), (ii) earthworms removed, counted and returned to the plot (D+), and (iii) undisturbed (U). Weekly methane flux measurements were made from April to November, 2010. Soil moisture and temperature were continually recorded. Methane flux measurements were also made three times over a 24 -h period at each site to quantify diurnal patterns. I also conducted a second experiment to examine the relationship between earthworm population size and soil properties, and methane flux that did not disturb the soil. I determined methane flux in these supplemental plots at seven randomly selected locations in an area of the field adjacent to the manipulated 
plot experiment. Once gas sampling was completed, I sampled the soil under each chamber for $\mathrm{pH}$, organic matter content, $\mathrm{NH}_{4}$ and $\mathrm{NO}_{3}$ concentrations, soil moisture, and soil temperature. Earthworms were counted, weighed and identified.

I also examined the potential effects of earthworms on acetoclastic and hydrogenotrophic methanogenesis, and on methane oxidation, using cast, burrow, and bulk soil from soils inoculated with Anecic and epi-endogeic earthworms, the two most common earthworm ecological groups found at the research sites, and a control soil. Soil from bulk, burrow or casts was transferred to microcosms with conditions manipulated to favor only one of the three processes - methane oxidation, hydrogenotrophic methanogenesis, or acetoclastic methanogenesis. Microcosms were periodically sampled for methane concentration in the headspace to determine process rates.

Mean ( \pm s.d.) methane flux (ng $\mathrm{CH}_{4}-\mathrm{C} / \mathrm{m}^{2} / \mathrm{sec}$ ) in the $\mathrm{U}$ treatment plots ranged from $-98 \pm 6$ to $-20 \pm 9$ at PF and $-42 \pm 7$ to $2 \pm 5$ at WAJ. Methane flux in the Dtreatment plots ranged from $-95 \pm 13$ to $-14 \pm 11$ at $\mathrm{PF}$ and $-46 \pm 11$ to $-4 \pm 4$ at WAJ. Mean methane flux in the $D+$ treatment plots ranged from $-73 \pm 12$ to $-14 \pm 12$ at PF and $-38 \pm 7$ to $-8 \pm 5$ at WAJ. Analysis of the data using a two-way repeated measures ANOVA showed no overall difference in methane flux among the three treatments at PF. On two out of a total 27 sampling dates, there was significantly higher methane consumption (more negative flux) in D- than in D+treatments. Furthermore, on three out of 27 sampling dates the D- treatment had significantly lower methane consumption than the D+ treatment. However, no there were no significant differences 
among treatments in earthworm population density or biomass at the end of the experiment.

By contrast, there was a significant overall difference in methane flux among treatments at the WAJ site, although there were no significant difference in earthworm population densities or biomass among treatments at the end of the experiment. Net methane consumption was significantly higher in D- than in D+treatments on seven out of a total of 26 sampling dates. The results from WAJ support the hypothesis that plots with earthworms removed should have higher net methane consumption than plots with earthworms, whereas results from PF suggest no effect from earthworm removal on methane flux. This suggests that the effect of earthworms on methane flux may be site-specific, contingent upon factors not quantified in this experiment.

For the supplemental plots, mean ( \pm s.d.) methane flux (ng $\mathrm{CH}_{4}-\mathrm{C} / \mathrm{m}^{2} / \mathrm{sec}$ ) ranged from $-80 \pm 15$ to $-17 \pm 4$ at $\mathrm{PF}$ and $-40 \pm 18$ to $-14 \pm 3$ at WAJ. There was no apparent relation between methane flux and earthworm population density or mass for either site. Population densities of earthworms ranged from $10 \mathrm{ind} . / \mathrm{m}^{2}$ on 19 August to 103 ind. $/ \mathrm{m}^{2}$ on 7 October at PF, and from 36 ind. $/ \mathrm{m}^{2}$ on 14 October to $132 \mathrm{ind} . / \mathrm{m}^{2}$ on 17 June at WAJ. Using a backward-elimination stepwise multiple regression analysis I examined methane flux as a function of earthworm population density and soil properties - moisture, temperature, $\mathrm{pH}, \mathrm{O} . \mathrm{M}$. content, $\mathrm{NH}_{4}, \mathrm{NO}_{3}$, and sampling date - as well as other earthworm parameters besides earthworm population density, including mass, ecological group, and life stage (juvenile or adult). Results showed no relation between methane flux and any earthworm parameter for either site. 
The microcosm experiments yielded evidence for an effect of earthworms on methane dynamics. A one-way ANOVA and Holm-Sidak all-pairwise comparison showed that the anecic cast treatment had a significantly lower methane oxidation rate than all other treatments in soil from both sites for $80 \%$ of the sampling events. All other treatments were statistically similar to each other, with the exception of the epiendogeic burrow soil at WAJ, which had a significantly higher methane oxidation rate than all other treatments on most sampling times. The anecic cast soil had significantly higher levels of nitrate and ammonium than all other treatments, suggesting an inhibitory effect of ammonium and/or nitrate on methane oxidation.

Results of a two-way ANOVA showed that there were no significant differences $(p>0.05)$ in rates of hydrogenotrophic methanogenesis among treatments at any time in soil from either site $\left(0.6 \pm 0.4\right.$ to $2.3 \pm 1.3\left(\mu \mathrm{g} \mathrm{C}-\mathrm{CH}_{4} / \mathrm{sec} / \mathrm{g}\right.$ soil $)$ in the $\mathrm{PF}$ soil and $0.6 \pm 0.4$ to $3.1 \pm 1.5\left(\mu \mathrm{g} \mathrm{C}-\mathrm{CH}_{4} / \mathrm{sec} / \mathrm{g}\right.$ soil $)$ in the WAJ soil), except at $\mathrm{t}=71 \mathrm{~h}$, when the epi-endogeic bulk soil had significantly higher rates of methanogenesis than the epi-endogeic burrow soil, the anecic burrow soil, and the anecic cast soil in the soil from PF. A two-way ANOVA showed no significant differences between rates of acetoclastic methanogenesis among treatments at any time in the PF soil. Acetoclastic methanogenesis rates ranged from 0 to $16.0 \pm 10.7 \mu \mathrm{g} \mathrm{CH}_{4}-\mathrm{C} / \mathrm{sec} / \mathrm{g}$ soil. There was no clear trend in the rate of methanogenesis over time. By contrast, there were significant differences in the rates of acetoclastic methanogenesis in WAJ soil at $115 \mathrm{~h}$ and $144 \mathrm{~h}$. At $115 \mathrm{~h}$, the epi-endogeic burrow treatment had significantly higher rates of methanogenesis than the control, the epi-endogeic bulk, the anecic burrow, and the anecic cast treatment. At $144 \mathrm{~h}$, the epi-endogeic burrow treatment had significantly 
higher rates of methanogenesis than the control, the epi-endogeic bulk, and the anecic burrow treatment. These results show that the ability of soil to consume methane was lowered by anecic earthworm activity in soil from both sites (anecic cast) as compared to soil with no earthworms (control). In addition, one earthworm treatment (epiendogeic burrow) at times (115h and $144 \mathrm{~h}$ ) had an effect of increasing acetoclastic methanogenesis in soil from WAJ as compared with soil from WAJ with no earthworms (control).

In the manipulated plots field experiment the majority of the differences were found at the W. Alton Jones site. This is in agreement with the results of the microcosm experiments, which suggest that earthworms may affect methane flux specifically by increasing acetoclastic methanogenesis and decreasing oxidation, and that effects may be site-specific. At PF, the decrease in methane oxidation as found in the anecic casts treatment in the microcosms may have occurred in the field but to a minimal degree, that which was not enough to cause a measurable difference. However, at WAJ, the combination of lower methane oxidation in anecic cast soil, paired with an increased acetoclastic methanogenesis in the epi-endogeic burrow soil, may drive differences in flux. 


\section{AKNOWLEDGEMENTS}

Sincere thanks to my major professor, José Amador, for all of his assistance and guidance. I would also like to thank my committee members, Mark Stolt and Thomas Boving, for their guidance, and Steve Alm for chairing my defense. Thanks to Janet Atoyan for her advice and technical expertise, and to undergraduate research assistants Andrew Giguere and Claire Staines for their hard work.

Thank you for assistance in site selection and management to Carl Sawyer, Research Associate of the Department of Plant Sciences and Entomology, and to Thomas Mitchell, director of the University's W. Alton Jones campus.

A special thanks to my loving family for their support, and to my wife Jessica, for her unwavering encouragement and inspiration. 


\section{PREFACE}

\section{Biographical Sketch}

Edward J. Avizinis was born in Rhode Island on May 24, 1982 of James and Catherine Avizinis. He grew up, with his two brothers Timothy and James, in Rockville, Rhode Island, where he conducted his earliest dirt-related experiments. He married Jessica Redinger in 2008 , and graduated from the University of Rhode Island in the spring of 2009, with a Bachelor of Science in Wildlife and Conservation Biology. Ed was admitted to the Natural Resources Science graduate program at U.R.I. in the fall of 2009. He currently lives in Greene, RI, with his family - Jessica, Vilka, Loki, and Murray - and works as a Wetland Biologist for a private environmental consulting company. 


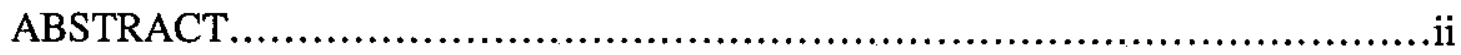

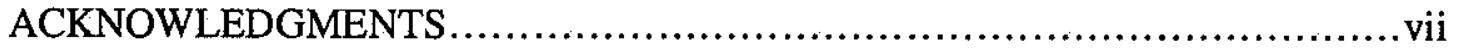

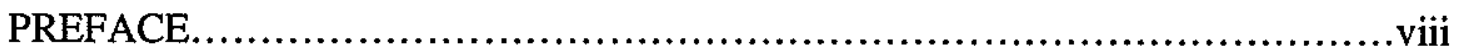

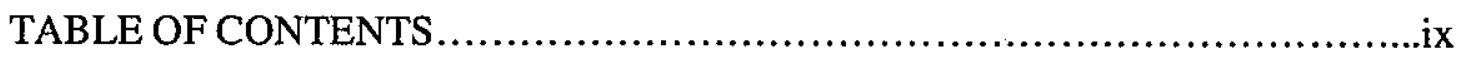

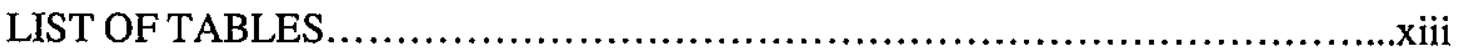

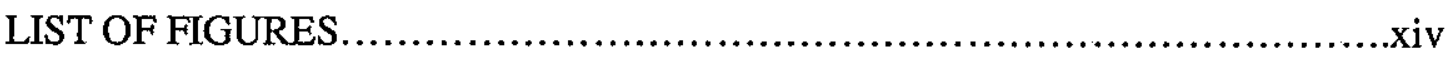

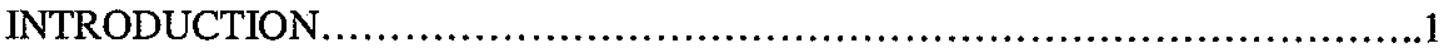

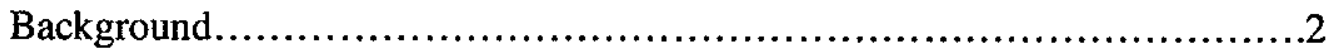

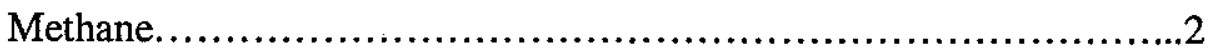

Earthworms.........................................................

Earthworm ecological groups....................................6

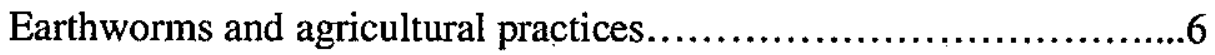

Description of the Study ...................................................

Field methane flux (manipulated plots) ............................

Field methane flux (supplemental plots) $\ldots \ldots \ldots \ldots \ldots \ldots \ldots \ldots \ldots \ldots \ldots . \ldots \ldots$ 
Microcosms.

Hypotheses......

Hypotheses for manipulated plots................................10

Hypotheses for supplemental plots................................10

Hypotheses for microcosms........................................11

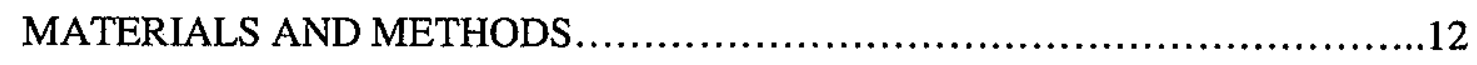

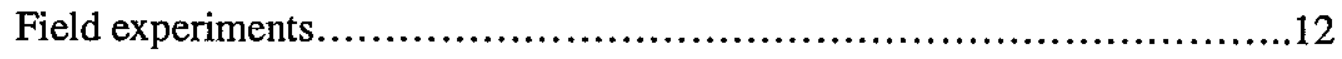

Manipulated plots.................................................12

Gas flux..........................................................

Supplemental plots.............................................15

Diurnal patterns...................................................

Sampling of supplemental plots...................................16

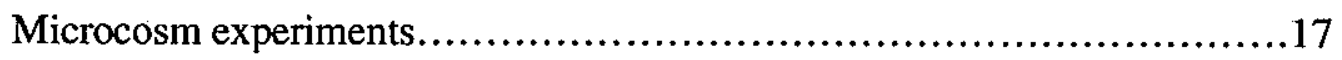

Earthworm mesocosms............................................17

Process rate measurements........................................18

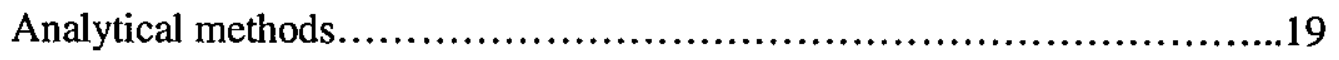

Methane concentration............................................. 
Methane flux

Soil properties

Data analysis.

Manipulated plots..................................................21

Supplemental plots..............................................21

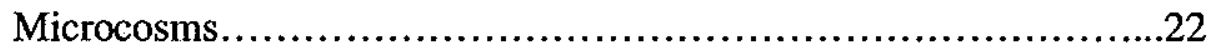

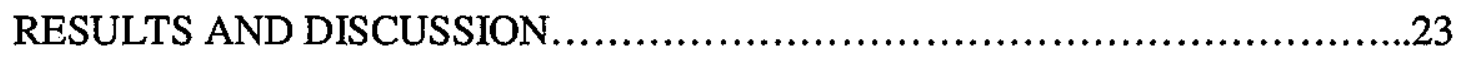

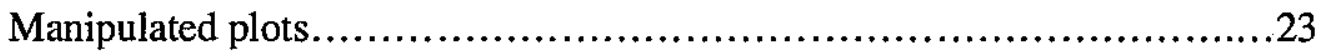

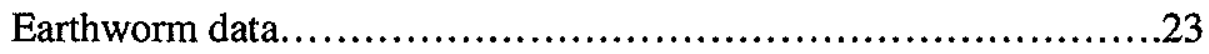

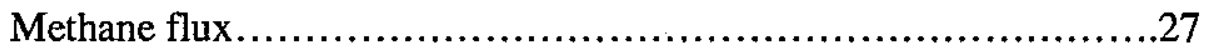

Diurnal patterns..................................................

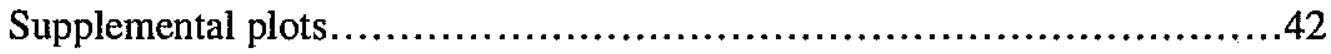

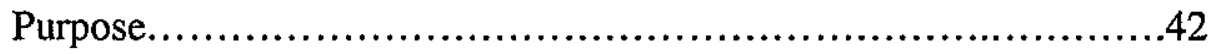

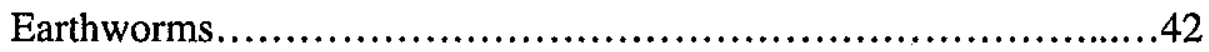

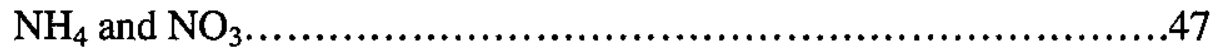

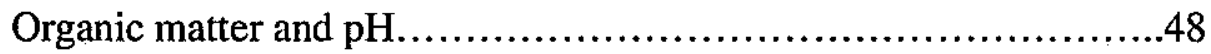

Methane flux.......................................................... 
Microcosm experiment..

Methane oxidation.....................................................55

Hydrogenotrophic methanogenesis................................59

Acetoclastic methanogenesis..................................62

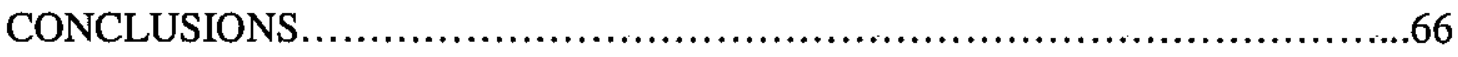

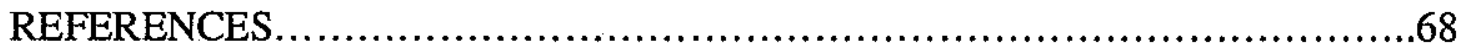




\section{LIST OF TABLES}

$\underline{\text { Table }}$

1. Soil profile description for Peckham Farm.....................................13

2. Soil profile description for $\mathrm{W}$. Alton Jones.....................................13

3. Mass, count, and ecological group of earthworms inoculated into

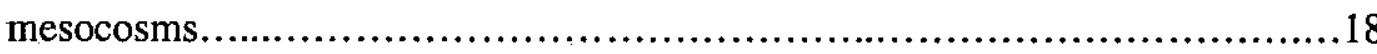

4. Significant differences $(p \leq 0.05)$ identified using two-way repeated measures ANOVA among treatments (D-, D+, and U) within date at Peckham Farm.

5. Significant differences $(p \leq 0.05)$ identified using two-way repeated measures ANOVA among treatments (D-, D+, and $\mathrm{U}$ ) within date at $\mathrm{W}$. Alton Jones........31

6. Mean water filled pore space (WFPS) for each treatment (D-, D+, and U) at 6:00, 12:00, and 16:00 h on 30 August 2010 at Peckham Farm

7. Mean water filled pore space (WFPS) for each treatment (D-, D+, and U) at 6:00, 12:00, and 16:00 h on 1 September 2010 at W. Alton Jones.

8. Results of a stepwise multiple regression analysis with backward elimination ( $\alpha=0.05$ to eliminate) used to identify earthworm variables or soil properties affecting methane flux within the supplemental plots at Peckham Farm.

9. Results of a stepwise multiple regression analysis with backward elimination ( $\alpha=0.05$ to eliminate) used to identify earthworm variables or soil properties affecting methane flux within the supplemental plots at W. Alton Jones 


\section{LIST OF FIGURES}

Figure

Page

1. Schematic diagram of plot and treatment assignments for manipulated plots at Peckham Farm and W. Alton Jones... . ......................................

2. Mean methane flux $(n=8)$, soil temperature $(n=3)$, and volumetric water content $(n=3)$ of manipulated plots at Peckham Farm as a function of time

3. Mean methane flux $(n=8)$, soil temperature $(n=3)$, and volumetric water content $(\mathrm{n}=3)$ of manipulated plots at $\mathrm{W}$. Alton Jones as a function of time

4. Mean $(n=8)$ earthworm counts and biomass for October 2009 and October 2010 the experiment from the manipulated plots at Peckham Farm.

5. Mean $(n=8)$ earthworm counts and biomass before (October 2009) and after (October, 2010) the experiment from the manipulated plots at Peckham Farm....36

6. Methane flux ( $n=8)$, soil moisture $(n=3)$ and soil temperature $(n=3)$ for each treatment (D-, D+, and $\mathrm{U}$ ) at 6:00, 12:00, and 16:00 h on 30 August 2010 at Peckham Farm.

7. Methane flux $(n=8)$, soil moisture $(n=3)$ and soil temperature $(n=3)$ for each treatment (D-, D+, U) at 6:00,12:00, and 16:00 h on 1, September 2010 at W. Alton Jones

8. Earthworm population density $(n=7)$ by ecological group and proportion of adult to juvenile earthworms in the supplemental plots at Peckham Farm.

9. Earthworm population density $(n=7)$ by ecological group and proportion of adult to juvenile earthworms in the supplemental plots at W. Alton Jones

10. Mean $(n=7)$ methane flux, soil moisture, and soil temperature at Peckham 
Farm for supplementary plots.

11. Mean ( $\mathrm{n}=7$ ) methane flux, soil moisture, and soil temperature for W. Alton

Jones supplementary plots

12. Levels of soil $\mathrm{NO}_{3}, \mathrm{NH}_{4}$, organic matter, and $\mathrm{pH}$ in supplementary plots $(\mathrm{n}=7)$

at Peckham Farm

13. Levels of soil $\mathrm{NO}_{3}, \mathrm{NH}_{4}$, organic matter, and $\mathrm{pH}$ in the supplementary plots $(\mathrm{n}=7)$ at W. Alton Jones

14. Mean (s.d.) methane oxidation rates for bulk, burrow, or cast soils from mesocosms containing different earthworm treatments - no earthworms (control), epi-endogeic (epi-endo), or anecic earthworm from Peckham Farm or W. Alton Jones soils. .56

15. Mean $(n=3)$ soil nitrate and ammonium levels at the end of the methane oxidation assay experiment for soils from Peckham Farm and W. Alton Jones....58

16. Mean $(n=3)$ hydrogenotrophic methanogenesis rates for bulk, burrow, or cast soils from mesocosms containing different earthworm treatments - no earthworms (control), epi-endogeic (epi-endo), or anecic earthworms from Peckham Farm or W. Alton Jones soils.

17. Mean $(n=3)$ nitrate and ammonium levels from microcosm soil after hydrogenotrophic methanogenesis assay for soils from PF and WAJ

18. Mean $(n=3)$ acetoclastic methanogenesis rates for bulk, burrow, or cast soils from mesocosms containing different earthworm treatments - no earthworms (control), epi-endogeic (epi-endo), or anecic earthworms from Peckham Farm or W. Alton Jones soils. 
19. Mean ( $\mathrm{n}=3$ ) ammonium levels from microcosm soil after acetoclastic methanogenesis assay for soils from Peckham Farm and W. Alton Jones.......64 


\section{INTRODUCTION}

Methane is a potent greenhouse gas that is second only to carbon dioxide in terms of radiative forcing potential ${ }^{1}$. Atmospheric methane levels are currently $148 \%$ those of pre-industrial revolution levels (Trenberth et al,, 2007). Methane is produced and consumed by microorganisms in soil, depending on soil conditions. Earthworms may have an effect on the flux of methane in soil by altering soil pore space, aeration, moisture content, and organic carbon availability, all of which can affect the activities of microorganisms responsible for methane production and consumption.

In the northeastern United States earthworms are relatively recent arrivals. Native earthworms were extirpated by the last glaciation, approximately 12,000 years ago, and the area remained earthworm-free until colonization by Europeans in the 1700s (Hale, 2007). Recent research has shown that some forms of conservation tillage can lead to a two-fold increase in earthworm population density relative to conventional tillage (Uren and Haines, 1999). Farming practices in the United States are shifting towards increased adoption of conservation or no-tillage practices in an effort to increase carbon sequestration and improve soil quality (West and Marland, 2000). This has led to the expansion of earthworm populations in agricultural soils in the northeastern United States.

I conducted two field experiments to determine whether earthworms have an effect on methane flux in two Rhode Island pastures. In addition, I conducted experiments to examine some of the mechanisms by which earthworms may affect

\footnotetext{
${ }^{1}$ Radiative forcing potential is a unit used to measure the overall effect of a greenhouse gas taking into account the abundance of the gas in the atmosphere.
} 
methane flux. The first field experiment was designed to determine if the presence or absence of earthworms had an effect on methane flux. Permanent plots were established in pastures and three treatments $(n=8)$ were established: (i) soil dug up and earthworms removed, (ii) soil dug up and earthworms counted, weighed and returned, and (iii) unaltered areas with an ambient number of earthworms. A closed-chamber method was used to measure methane flux.

The second field experiment was designed determine the relationship between methane flux and earthworm variables (population density, biomass, ecological group, and life stage) as well as soil properties (including $\mathrm{pH}$, organic matter content, inorganic nitrogen, and soil temperature and moisture). Methane flux was determined using closed chambers in an area adjacent to the fields in the first experiment, followed by soil sampling for earthworms and soil properties.

Lastly, microcosms were set up to determine how potential rates of net methane production and consumption were affected by earthworms. Bulk, burrow, or cast soil from each site were placed in vials and conditions manipulated to select for methane production or consumption to determine effects on potential rate of these processes.

\section{Background}

Methane. Methane is a potent greenhouse gas that has consistently risen in atmospheric concentration from a pre-industrial value of $0.715 \mathrm{ppmv}$ in 1750 to 1.774 ppmv in 2005 (Trenberth et al., 2007). Methane has a radiative forcing value of 0.48 $\mathrm{W} / \mathrm{m}^{2}$, second only to carbon dioxide (Trenberth et al., 2007). In other words, for 
every square meter of tropopause, methane is responsible for absorbing 0.48 Watts of radiation energy into the atmosphere (Ramaswamy et al., 2001). With a larger quantity of methane in the atmosphere, many studies predict the effects of global climate change will be expedited.

Soil is an important net sink for methane from the atmosphere; however, there are soils that produce methane as well. Methane is produced and consumed by microorganisms in soil, depending on soil conditions. It is produced by methanogenic Archaea such as Methanobacterium thermoautotrophicum, Methanofollis aquaemaris, and Methanococcus maripaludis that require anaerobic conditions (Sheppard et al., 2005). These produce methane through two main pathways: (i) hydrogenotrophic methanogenesis, and (ii) acetoclastic methanogenesis. In hydrogenotrophic methanogenesis, methanogens use $\mathrm{CO}_{2}$ as an electron acceptor (Eq. 1):

$$
\text { [1] } 4 \mathrm{H}_{2}+\mathrm{CO}_{2} \rightarrow \mathrm{CH}_{4}+2 \mathrm{H}_{2} \mathrm{O}
$$

In acetoclastic methanogenesis, methanogens use acetate, a product of anaerobic fermentation, to produce methane (Eq. 2):

$$
\text { [2] } \mathrm{CH}_{3} \mathrm{COO}^{-}+\mathrm{H}_{2} \mathrm{O} \rightarrow \mathrm{CH}_{4}+\mathrm{HCO}_{3}^{-}
$$

Methane is consumed by methane-oxidizing aerobic bacteria such as Methylococcus capsulatus, Methylomicrobium album, and Methylomonas methanica (Brock et al., 1994). These bacteria use methane monooxygenase to oxidize methane (Holmes et al., 1995). They use methane as a source of carbon and energy, producing carbon dioxide and water (Eq. 3) (Schimel and Holland, 2005):

$$
\text { [3] } \mathrm{CH}_{4}+2 \mathrm{O}_{2} \rightarrow \mathrm{CO}_{2}+2 \mathrm{H}_{2} \mathrm{O}
$$


It is not uncommon for these processes to occur simultaneously in a soil. When soil is dry and aerobic conditions are prevalent, aerobic microorganisms such as methane oxidizers thrive. However, anaerobic conditions may be present within soil aggregates if microorganisms within the aggregate consume oxygen faster than the rate of diffusion. depleting the inner area (Myrold, 2005). Earthworms may affect the occurrence of these microsites, thus altering the balance of aerobic and anaerobic processes. Whether the rate of methanogenesis is greater than methane oxidation (or vice versa) determines whether a soil is a net source or sink for methane. For example, freshwater wetland soils generally are net sources of methane to the atmosphere, whereas unsaturated upland soils are generally considered to be sinks for methane, consuming between 3\% and 9\% of total atmospheric methane (Schimel and Holland, 2005).

Earthworms. There is no evidence to suggest the presence of native earthworms in the area covered by ice of the Wisconsinan glaciation, including Rhode Island. Native earthworms that may have been present in this area were extirpated by glaciation (Hendrix et al., 2006). This glaciated area remained earthworm-free until colonization by Europeans introduced exotic earthworms in crops, mulch, and other soil-bearing vehicles (Hale, 2007). Some of these exotic earthworm species have also been introduced to other areas of the North American continent, which continue to spread (Hendrix and Bohlen, 2002).

Earthworms play a key role in upland agroecosystems (Edwards, 2004) where they translocate crop residues, accelerate decomposition and nutrient mineralization, increase inorganic $\mathrm{N}$, alter the physical properties of soil (e.g. pore size distribution, 
water retention, gas diffusion), and the size, composition and activities of microbial and faunal communities. These effects overlap with controls on $\mathrm{CH}_{4}$ flux in soil, including availability of precursors, inhibitors, electron donors and acceptors, the size and location of relevant microbial populations, and the establishment of conditions necessary for their activities. Specifically, earthworms create burrows in the soil that increase the bulk density within the drilosphere through compaction along the burrow lining caused by radial and axial pressures, along with mucus secretion (Brown et al., 2000). This can cause an increase in water retention in the burrows, promoting the formation of anaerobic microsites (Devliegher and Verstraete, 1997) favorable for methane production. Earthworms also increase incorporation and decomposition of organic materials - by increasing surface area through conminution - which leads to an increase in production of methanogenic precursors such as acetate, formate, and other organic substrates (Brown et al., 2000). In addition, the earthworm gut provides a mobile anaerobic zone that, in Lumbricus terrestris, has been found to produce hydrogen, a required precursor in hydrogenotrophic methanogenesis (Wust et al., 2009). However, methane is not emitted from the earthworm gut, so they are not expected to contribute directly to methanogenesis (Karsten and Drake, 1995).

Earthworms secrete mucus rich in nitrogen (Parkin and Berry, 1999) which, in the form of ammonia and nitrate, has been shown to inhibit the ability of some species of methane-oxidizing bacteria to consume methane (King and Schnell, 1994). Because of the structural similarities between ammonia and methane, ammonia competes with methane for enzyme binding sites, therefore interfering with methane oxidation (Bedard and Knowles, 1989; Dunfield and Knowles, 1995). Ammonia- 
oxidizing bacteria can oxidize methane as well (Conrad and Rothfuss, 1991). Holmes et al. (1995) found that methane monooxygenases are evolutionarily related to ammonia monooxygenases.

Earthworm ecological groups. Earthworms can be placed into three main ecological groups - epigeic, endogeic, and anecic - based primarily on feeding and burrowing strategies (Bouché, 1977). Epigeic earthworms live for the most part on the surface and consume plant detritus and other organic material (Blaire et al., 1995). Adults are generally 2-7 cm long and are pigmented (Amador and Görres, 2005). Endogeics generally live within the soil and consume soil and organic matter (Blaire et al., 1995). They are generally not pigmented and make temporary continuous burrows (Amador and Görres, 2005). As they consume and excrete soil, casts are formed, which can be deposited on the soil surface and line the burrow walls. The anecic group consists of earthworms that create semi-permanent vertical burrows in the soil. The worms pull organic material from the surface and bring it into the burrow. They produce casts and build middens at the entrance of the burrow with a mixture of cast material and semi-incorporated organic material (Blaire et al., 1995). Epigeic and endogeic earthworms may effect methane flux in soil equally through their feeding and burrowing activities, whereas anecic earthworms may have a greater comparative effect due to their larger size and ability to bring organic matter from the surface into the soil profile.

Earthworms and agricultural practices. An abundant earthworm population is considered a sign of good soil quality (Linden et al., 1994). Estimates of earthworm population density in agricultural soils are one of 20 key indicators included by the 
USDA Natural Resources Conservation Service (NRCS) in its Guidelines for Soil Quality Assessment in Conservation Planning (USDA-NRCS Soil Quality Institute, 2001), a manual used by soil conservationists throughout the U.S. to advise farmers. There is evidence that some soil conservation agricultural practices lead to higher earthworm populations. For example, some forms of conservation tillage can lead to a two-fold increase in earthworm population as compared with conventional tillage (Haines and Uren, 1990). Other studies have shown that earthworm population densities and biomass were $70 \%$ higher in no-till agroecosystems than in conventional systems (Parmelee et al., 1990). As farming practices in the United States shift towards increased adoption of conservation tillage - in an effort to minimize soil erosion and increase carbon sequestration - a better understanding of the impact that earthworms have on greenhouse gas production and consumption processes is needed for management of greenhouse gases.

\section{Description of Study}

Field methane flux (manipulated plots). To examine the relationship between earthworms and methane flux in temperate pastures, I established twenty-four experimental plots in November of 2009 in two managed pastures; one at Peckham Farm, in Kingston, and a second one at the W. Alton Jones campus of the University of Rhode Island, in West Greenwich, both in southern Rhode Island (Fig. 1). Three different treatments ( $n=8$ ) were implemented: (i) earthworms removed (D-); (ii) earthworms removed, counted and returned to plots (D+); and (iii) undisturbed (U). Each plot was fitted with a closed-chamber for measurement of methane flux. Weekly methane flux measurements were made from 15 April 2010 to 21 October 2010. In 
Figure 1. Schematic diagram of plot and treatment assignments at Peckham Farm and W. Alton Jones. Plots were randomly assigned and randomly selected within the grid. Letters indicate plot identification labels. Letters $\mathrm{A}-\mathrm{H}$ were designated as $\mathrm{U}$ (unaltered) treatment, letters I - P were designated as D- (earthworms removed) treatment, and letters $\mathrm{Q}-\mathrm{X}$ were designated as $\mathrm{D}+$ (earthworms counted, weighed, and returned) treatments. Shaded areas indicate treatment.

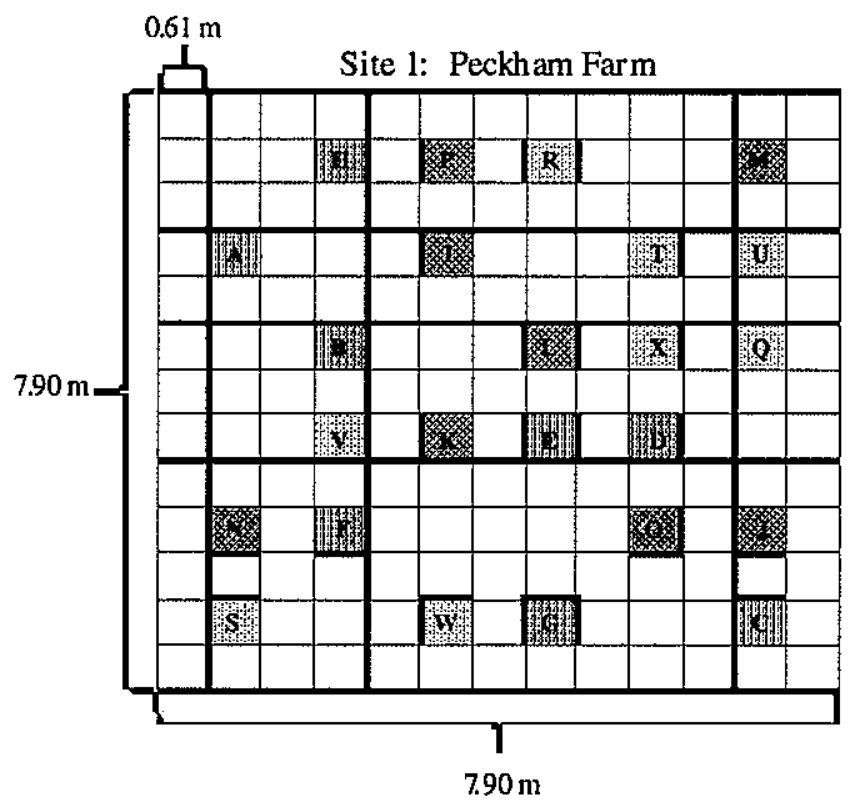

Site 2: W. Alton Jones

\begin{tabular}{|c|c|c|c|c|c|c|c|}
\hline & & & & - & & & \\
\hline$\overline{1}$ & & $y$ & & 0 & & & Man \\
\hline & & & & & & & \\
\hline & . & & Kk & Sz & & 㽝 & ry \\
\hline & & & & . & & & \\
\hline W & & . & . & $\mathrm{W}$ & & XIx & \\
\hline & & & & & & . & 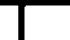 \\
\hline & & 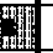 & 11 & & & $x_{H}$ & . \\
\hline & & & & & & & \\
\hline 残 & & 1 & & 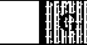 & & Har & 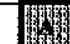 \\
\hline & & & & & & & \\
\hline & & 躍 & ly & & & SzS & 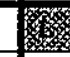 \\
\hline & & & & & & & 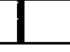 \\
\hline
\end{tabular}

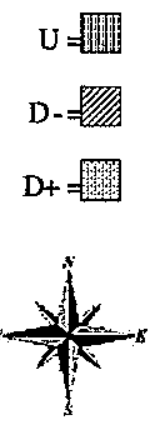


addition, soil moisture and temperature were continually recorded. Earthworm population density and community composition were determined at the end of the experiment in addition to soil properties - ammonium and nitrate concentrations, soil organic matter, and $\mathrm{pH}$.

Field methane flux (supplemental plots). Every two weeks from April to November, 2010, I inserted seven closed chambers into the soil at seven randomly selected locations in an area of the field adjacent to the manipulated plot experiment. After a 30-minute resting period (to allow for mitigation of the effects of insertion (Norman et al., 1997)), I measured methane flux. Once gas sampling was completed, I sampled the soil under the chamber. Earthworms were counted and brought back to the lab to be weighed and identified using the Hale (2005) identification key. Soil temperature was recorded at the time of sampling and soil samples were taken for lab analysis of moisture content, ammonium and nitrate concentration, $\mathrm{pH}$, and organic matter content.

Microcosms. I examined the potential effects of earthworms on acetoclastic and hydrogenotrophic methanogenesis, and methane oxidation using soil samples from cast, burrow, and bulk soil from the two most common earthworm ecological groups found at the research sites, as well as a control soil without earthworms. Conditions were manipulated to favor only one of the three processes - methane oxidation, hydrogenotrophic methanogenesis, or acetoclastic methanogenesis. Samples were incubated and periodically sampled for methane concentration in the headspace to determine process rates.

\section{Hypotheses}




\section{Hypotheses for manipulated plots}

1. All treatments will be sinks for methane (negative flux) as is typical for temperate upland pastures. However, plots with higher earthworm population densities and/or biomass (D+) will have less negative methane flux than plots without earthworms (D-). I expect that this will happen as a result of a simultaneous decrease in methane oxidation and an increase in methane production in relation to high earthworm population densities and/or biomass.

2. Increased water infiltration and retention in soils with more earthworms, will negatively impact conditions for methane oxidizing bacteria and promote conditions for methanogenesis. Soil moisture content will be lower in D-plots than U or D+ plots. Since earthworm counts are expected to be similar between $\mathrm{U}$ and $\mathrm{D}+$ plots, I do not expect to see differences in soil moisture or methane flux.

\section{Hypotheses for supplemental plots}

1. All plots will be a sink for methane (negative flux). However, I expect to see a positive correlation between methane flux and earthworm population densities and biomass.

2. I expect to see a positive correlation between levels of nitrate and ammonium, and plots with higher earthworm population density, which may lead to the inhibition of methane oxidation, decreasing net methane consumption (King and Schnell, 1994). 
3. Moisture will have a positive correlation with methane flux, and earthworm count and biomass will have a positive relation with soil moisture. Plots with higher population density and biomass will increase soil moisture by increasing water infiltration and retention.

\section{Hypotheses for microcosms}

1. I expect to see significantly higher acetoclastic and hydrogenotrophic methanogenesis in the anecic cast, anecic burrow, and epi-endogeic burrow soil treatments as compared with the anecic bulk, epi-endogeic bulk and control soil treatments as these soils are expected to have higher levels of methane precursors as well as a likely resident community of methanogens.

2. I expect to see significantly lower rates of methane oxidation in anecic cast, anecic burrow, and epi-endogeic burrow soil treatments as compared with the anecic bulk, epi-endogeic bulk and control soil treatments. It is likely that the anecic cast, anecic burrow, and epi-endogeic burrow soil have higher concentrations of nitrogen which can inhibit methane oxidation. In addition, these areas may have higher bulk density which may limit oxygen diffusion and increase the retention of soil moisture. 


\section{MATERIALS AND METHODS}

\section{Field Experiments}

Field experiments involved two different approaches. The first approach was designed to determine if removing earthworms from the soil has an effect on methane flux. This involved using field plots manipulated to have earthworms present or not, followed by long-term monitoring of methane flux. These are referred to as the "manipulated plots". The second approach was designed to determine whether or not there is a correlation between methane flux and different earthworm parameters and soil properties. These are referred to as the "supplemental plots". This involved determining methane flux prior to sampling for soil properties and earthworm parameters. These plots were sampled every other week at each site in randomly selected locations from an area immediately adjacent to the field where the manipulated plots were established.

Manipulated plots. Manipulated plots were established in November of 2009 at Peckham Farm (PF), Kingston, and at the URI W. Alton Jones (WAJ) campus in West Greenwich, both in southern Rhode Island. The experimental sites are located in similarly managed pastures that are mowed once per year in the fall with the plant material left on site. Common plant species found at both sites include: goldenrod (Salidago spp.), common milkweek (Asclepias syriaca), orchard grass (Dactylus glomerata), and kentucky bluegrass (Poa pretensis).

Particle size distribution analysis was conducted with soil from the first $30 \mathrm{~cm}$ for each site and a sandy loam texture was determined for both. A soil profile description was conducted using a bucket auger down to $102 \mathrm{~cm}$ (Tables 1 and 2). The sites were 
established on what would be considered a summit landscape position with minimal slope $(0-3 \%)$.

Table 1. Soil profile description for Peckham Farm in Kingston, Rhode Island.

\begin{tabular}{ccccc}
\hline $\begin{array}{c}\text { Depth } \\
(\mathbf{c m})\end{array}$ & Horizon & Color & Texture (field test) & Redox \\
\hline $0-46$ & Ap & 10YR 3/2 & Sandy loam & None \\
$46-66$ & Bw1 & 10YR 5/6 & Sandy loam & None \\
$66-87$ & Bw2 & 10YR 5/4 & Sandy loam & None \\
$87-102+$ & Bw3 & 10YR 6/4 & Sandy loam & $\begin{array}{c}\text { Few faint depletions } \\
(99 \mathrm{~cm})\end{array}$ \\
\hline
\end{tabular}

Table 2. Sample soil profile description for W. Alton Jones in West Greenwich, Rhode Island.

\begin{tabular}{ccccc}
\hline $\begin{array}{c}\text { Depth } \\
(\mathbf{c m})\end{array}$ & Horizon & Color & Texture (field test) & Redox \\
\hline $0-13$ & Ap1 & 10 YR 3/1 & Sandy loam & None \\
$13-46$ & Ap2 & 10 YR 3/2 & Sandy loam & None \\
$46-64$ & Bw1 & 10 YR 5/4 & Sandy loam & None \\
$64-86$ & Bw2 & 10 YR 5/3 & Sandy loam & $\begin{array}{c}\text { Few faint depletions } \\
\text { (74cm) }\end{array}$ \\
$86-102+$ & C & 10 YR 5/2 & Gravelly Sand & $\begin{array}{c}\text { Few faint depletions } \\
\text { few prominent } \\
\text { concentrations }\end{array}$ \\
\hline
\end{tabular}

Three replicated $(n=8)$ treatments were implemented: (i) earthworms removed (D-), (ii) earthworms removed, counted and returned to the plot (D+), and (iii) undisturbed (U). Within a $7.9 \mathrm{~m} \times 7.9 \mathrm{~m}$ area at each site, 24 plots ( 3 treatments $\times 8$ replicates/treatment $)(61 \mathrm{~cm} \times 61 \mathrm{~cm})$ were setup with a distance of $61 \mathrm{~cm}$ between plots. Treatments were assigned to plots using a random number generator along with 
a grid map of the area (Figure 1) that included all possible plot locations. Plots were identified with a letter $\mathrm{A}-\mathrm{X}: \mathrm{A}-\mathrm{H}$ were designated as $\mathrm{U}$ treatment; $\mathrm{I}-\mathrm{P}$ were designated as D- treatment, and $\mathrm{Q}-\mathrm{X}$ were designated as $\mathrm{D}+$ treatments. To dig the D- and D+ plots, a wooden $61 \mathrm{~cm} \times 61 \mathrm{~cm}$ template was placed on top of the area to be dug to ensure plot uniformity. Soil was dug down to $30.5 \mathrm{~cm}$ and placed on a tarpaulin. Immediately following removal, soil was hand-sorted to remove earthworms, which were placed in sealable bags and stored in a cooler. Once the soil was removed, the sides of the plots were lined with fiberglass mesh $(45.7-\mathrm{cm}$ wide, $30.5 \mathrm{~cm}$ below ground and $15.2 \mathrm{~cm}$ above) to allow for unaltered hydrology while minimizing earthworm migration in or out of the plots.

Earthworms were counted and weighed after they were rinsed in water to remove soil particles, and dried on paper towels. Earthworms from the D+ plots were brought back to their respective plots and were placed under the leaf litter and loose top soil to encourage reestablishment into the soil and to minimize death due to ultraviolet light exposure or predation. The plots were left to overwinter and gas sampling began the following spring.

Gas flux. Methane flux was determined using the closed-chamber method as described by Flessa et al. (2002). Each plot was fitted with a closed-chamber gas collector made from a 5-gal. cylindrical (15-cm radius) white plastic bucket $(24 \mathrm{~cm}$ height) with the bottom cut off that was inserted into the soil. The tops were fitted with an air-tight screw-cap (Gamma Seal Lid, Leaktite Corp., MA) with vacuum grease applied to the threading to create an airtight seal. Rubber septa were inserted into the lids to allow for gas sampling. The chambers were inserted into the soil to a 
depth of $15 \mathrm{~cm}$ ( $9 \mathrm{~cm}$ above ground) and the headspace volume of the chamber was measured.

In early spring, before gas sampling began, nine ( 3 replicates per treatment) Thermocron iButtons (Dallas Semiconductor, TX) were placed in randomly selected plots at a depth of $10 \mathrm{~cm}$ to record soil temperature every hour. In addition, nine EC-5 soil moisture sensors connected to Em5b data loggers (Decagon Devices, Inc., WA) were placed at a depth of $10 \mathrm{~cm}$ to record soil moisture every hour.

Sampling of manipulated plots. A sampling event began by placing the lids on all 24 chambers at a given site. As lids were placed on the chambers, a gas sample was taken from five random plots to provide an ambient methane concentration. Gas samples were collected with a $20-\mathrm{ml}$ gas-tight syringe, drawing out $15 \mathrm{ml}$ and injecting that back into the chamber twice to mix up the headspace gases in the chamber and homogenize the sample. The third, 15-ml sample was injected into an evacuated, 12-ml Vacutainer vial (Labco Ltd, U.K.) at which point the syringe plunger was released to equilibrate to atmospheric pressure. Gas samples were taken 30 and $60 \mathrm{~min}$ after the lid was placed on the chamber. The temperature of the air within the chambers was also recorded using an additional chamber fitted with a digital thermometer (Fisher Scientific, Pittsburgh, PA).

Diurnal patterns. An additional experiment was conducted using the manipulated plots to assess the patterns of methane flux at different times of the day. Three different methane flux measurements were made using the same method described above at 6:00, 12:00, and 16:00 h (EST) at each site on 30 August at PF and 
1 September at WAJ. Soil temperature and moisture were recorded as described above.

Sampling of supplemental plots. The same type of gas chamber was used in the sampling of the supplemental plots as was used in the manipulated plots; however, the chambers were inserted into the soil 30 minutes prior to sampling. Seven plot locations were randomly selected every other week at each site by creating a site map of all possible sampling locations and using a random number generator. After an area was sampled once it was removed from the site grid to avoid resampling the same location. Once plot locations were determined, the chambers were placed on the soil surface. A knife was used to cut into the soil and chambers were pounded into the soil using a rubber mallet. After a resting period of $\sim 30$ min., lids were placed on the chambers and methane flux was measured as described above. After gas sampling was completed, soil from the area under the chamber was dug down to $30.5 \mathrm{~cm}$ to collect earthworms. The specimens were brought to the lab where they were washed, weighed, counted, and identified to species using a stereo microscope and the key published by Hale (2007). This key uses external morphological characteristics such as position of setae, location of clitellum, and other anatomical indicators to identify earthworms. In addition to the three primary groups (epigeic, endogeic, and anecic), I included the epi-endogeic sub-group as described by Hale (2007). The most common earthworm species identified in this study, Lumbricus rubellus, belongs to this group. Epi-endogeic earthworms have characteristics such as pigmentation and surface organic matter consumption - similar to epigeic earthworms - but also create burrows and consume soil like the endogeic earthworms (Hale, 2007). 
Soil samples were saved for analysis of soil properties, including moisture, ammonium and nitrate levels, organic matter content, and $\mathrm{pH}$. In addition, soil temperature data collected from the $\mathrm{U}$ manipulated plots was used in the analysis of results from the supplemental plots.

\section{Microcosm experiments}

Earthworm mesocosms. The effects of earthworms on the potential rate of methane oxidation, hydrogenotrophic methanogenesis, and acetoclastic methanogenesis were examined in vitro in accordance with Nesbit and Breitenbeck (1992). Three mesocosms per site were established in the laboratory in order to obtain cast, burrow, bulk soil samples from anecic earthworms, burrow, and bulk soil from epi-endogeic earthworms, and a control soil with no earthworms. Each mesocosm (70 $\mathrm{cm}$ height $\times 13 \mathrm{~cm}$ width $\times 3 \mathrm{~cm}$ depth) was constructed from Plexiglas and was filled with soil from either site to a depth of $60 \mathrm{~cm}$. These mesocosms were similar in design to a typical ant farm. The vertical distribution of soil horizons in the field was replicated in the mesocosms. Small holes were drilled in the bottom of the mesocosms and the mesocosms were placed in water troughs to maintain soil moisture by capillary action. Approximately $10 \mathrm{~g}$ of leaf litter collected from each site was placed on the soil surface to provide food for earthworms. Three treatments were employed for each site (i) anecic earthworms, (ii) epi-endogeic earthworms, and (iii) no earthworms (control). The initial earthworm count and mass in each mesocosm is shown in Table 3. 
Table 3. Mass, number, and ecological group of earthworms inoculated into mesocosms.

\begin{tabular}{clcc}
\hline Site & Treatment & $\begin{array}{c}\text { Earthworm } \\
\text { number }\end{array}$ & Earthworm mass (g) \\
\hline Peckham Farm & Anecic & 3 & $0.63,0.48,0.31$ \\
& Epi-endogeic & 3 & $0.53,0.30,0.28$ \\
& None (control) & 0 & - \\
W. Alton Jones & & & \\
& Anecic & 3 & $0.80,0.24,0.37$ \\
& Epi-endogeic & 3 & $0.43,0.50,0.44$ \\
& None (control) & 0 & - \\
\hline
\end{tabular}

After an approximately 90 day incubation period at $20^{\circ} \mathrm{C}$, mesocosms were dismantled and samples of burrow, bulk, and cast soil were obtained for the anecic treatment; burrow and bulk soil from the epi-endogeic treatment; and bulk soil from the control treatment. The front piece of plexiglass was removed and burrow soil was collected within $1 \mathrm{~cm}$ of the burrow wall with tweezers from multiple locations within a treatment to generate a composite sample that subsamples were taken from. Bulk soil was collected from areas at least $3 \mathrm{~cm}$ away from burrow walls. Cast soil was sampled from the surface from locations visually identified as casts (Parkin and Berry, 1999).

Process rate measurements. To measure acetoclastic methanogenesis $(n=3)$, $1 \mathrm{~g}$ (fresh weight) of soil was placed in a $12-\mathrm{ml}$ resealable vial along with $5 \mathrm{ml}$ of sterile $20 \mathrm{mM}$ acetate solution. The vials were sealed and the gases in the headspace exchanged with ultrapure $\mathrm{N}_{2}$. To measure hydrogenotrophic methanogenesis $(n=3)$, a slurry with $1 \mathrm{~g}$ (fresh weight) of soil and $5 \mathrm{ml}$ water was placed in a 12-ml resealable vial and the headspace gases exchanged with a $80 \% \mathrm{CO}_{2} / 20 \% \mathrm{H}_{2}$ mixture (Airgas East, Inc., NH). Vials were incubated on a shaker in the dark at $20^{\circ} \mathrm{C}$. A $1.0-\mathrm{ml}$ 
sample of headspace gases was analyzed daily to determine the concentration of methane. After each sampling the headspace gases in the vial were exchanged with either $\mathrm{N}_{2}$ or $80 \% \mathrm{CO}_{2} / 20 \% \mathrm{H}_{2}$ mixture as appropriate.

To determine rates of methane oxidation ( $\mathrm{n}=3$ ), $2 \mathrm{~g}$ (fresh weight) of soil was placed in 12-ml vials and headspace gases replaced with a mixture of methane in air (1.997 ppmv) (Airgas East, Inc., $\mathrm{NH}$ ) incubated at $20^{\circ} \mathrm{C}$ in the dark. A $1.0-\mathrm{ml}$ sample of headspace gases was removed and the headspace gases were exchanged with the mixture of methane in air. Measurements were made on soil adjusted to $20 \%$ waterfilled pore space (WFPS) to optimize oxidation, following a preliminary experiment to determine optimal water content for soil samples at different moisture levels $(10 \%$, $20 \%, 30 \%, 50 \%$ WFPS). For WAJ samples, measurements were taken at 20, 42, 64, 95, and $120 \mathrm{~h}$. For PF samples, measurements were taken at $18,42,62,91$, and $118 \mathrm{~h}$. WFPS was determined based on soil bulk density measurements made by use of the clod sample method. Multiple soil clods ( $n=3$, per site) were oven-dried and this mass was divided by the volume of the clod sampling container.

\section{Analytical Methods}

Methane concentration. Gas samples were analyzed using a model GC-14A gas chromatograph (Shimadzu Scientific Instruments, Inc., Columbia, MD) using Ultra Zero air to provide oxygen for the flame ionization detector and Ultra High purity hydrogen as a carrier gas (Airgas East, Inc., Salem, NH). The instrument was calibrated at the beginning of each sampling day using $2.020 \mathrm{ppmv}$ and $49.38 \mathrm{ppmv}$ (Airgas East) methane standards. A 1.0-ml subsample was injected into the GC using a 2.0-ml Pressure-Lok gas syringe (Vici Precision Sampling, Inc., Baton Rouge, LA). 
A peak Simple Chromatography Data Acquisition System (SRI Model 333, SRI

Instruments, Inc., Torrence, CA) was used to collect and analyze data.

Methane flux. Methane concentration for a given sample at a given time was calculated using the ideal gas law (Eq. 4).

$$
\text { [4] PV=nRT }
$$

where,

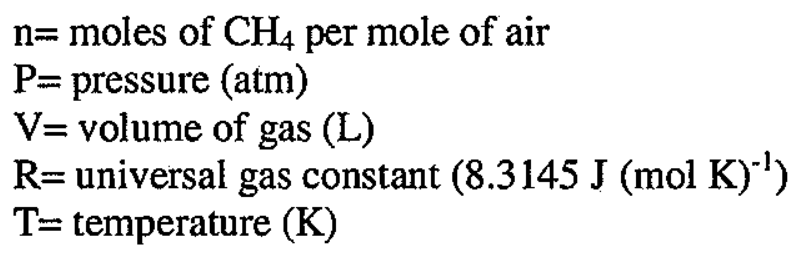

This was used to determine the concentration of methane in a 1-ml sample of gas at 0,30 , and 60 min. These data were separated by treatment and plotted as nanomoles of $\mathrm{CH}_{4}$ vs. time. Slope and correlation coefficient $\left(\mathrm{R}^{2}\right)$ were then determined for each plot. The data were assumed to follow a linear trend because the processes of methane production and consumption were not expected to change during the 1-hour sampling period sufficiently to cause a deviation from linearity. For a given treatment with eight curves plotted (one per plot), the four curves with the highest $R^{2}$ values were used to determine outliers. The curves with the lowest $R^{2}$ values (potential outliers) were identified as data points that were outside of the range created by the four curves with the highest $\mathrm{R}^{2}$ values. These outlier data points were attributed to error - i.e. sampling error, injection error, etc. - and were omitted from data analysis. The mass of methane, the area of soil surface under the chamber, and time were used to calculate flux (in $\mathrm{ng} \mathrm{CH}_{4}-\mathrm{C} \mathrm{m}^{-2} \mathrm{sec}^{-1}$ ) for each plot. 
Soil properties. Ammonium and nitrate were extracted using $1 \mathrm{~N} \mathrm{KCl}$ at a soil/extractant ratio of $1: 10(\mathrm{wt} / \mathrm{vol})$ (Keeney and Nelson, 1982). The extracts were filtered and the filtrate analyzed colorimetrically using the method of Keeney and Nelson (Keeney and Nelson, 1982) and a Powerwave 340 microplate spectrophotometer (Bio Tek, Winooski, VT).

Soil pH was determined (Soil Survey Laboratory Methods Manual, 1996) using 1:5 soil/water ratio and a pH electrode (Denver Instruments, Bohemia, NY). The $\mathrm{pH}$ meter was calibrated before analysis with $\mathrm{pH} 4,7$, and 10 buffers.

Soil moisture and organic matter content were determined according to the Soil Survey Laboratory Methods Manual (1996). Triplicate soil samples ( $5 \mathrm{~g}$ ) from each plot were weighed, oven-dried at $105^{\circ} \mathrm{C}$ for $24 \mathrm{~h}$, and weighed again to determine gravimetric moisture content. Oven-dried samples were then placed in a $550^{\circ} \mathrm{C}$ muffle furnace (Cole-Parmer Instrument Co., Vernon Hills, Il) for $5 \mathrm{~h}$ and then weighed again. Loss on ignition was calculated from the difference in mass.

\section{Data Analysis}

Manipulated plots. To determine if earthworms affect methane flux, differences in methane flux between treatments were determined using a two-way repeated measures ANOVA with time as one factor and treatment (with three levels $\mathrm{U}$, D+, and D-) as the second factor using SAS 3.0 (Altera Corp., San José, CA). The effect of treatment on soil moisture and temperature values were determined using a one-way ANOVA (Sigma Plot 11.0, Systat Software, Inc., San José, CA).

Supplemental plots. Multiple linear stepwise regression with backward elimination ( $\alpha>0.05$ to eliminate) (Minitab 16, Minitab, Inc., State College, PA) was 
used to analyze the relationship between methane flux and biotic and abiotic variables. Methane flux was the dependent variable and was tested against the independent variables - time, nitrate, ammonium, soil moisture and temperature, $\mathrm{pH}$ - within each of the earthworm categories - adult, juvenile, epigeic, epi-endogeic, anecic, endogeic, earthworm count, and earthworm mass.

Microcosms. Potential rates of methanogenesis and methane oxidation were calculated based on averages of triplicates for each treatment calculated for each sampling time interval. A one-way ANOVA was used to determine differences between treatments - anecic, epi-endogeic, and control - and between groups - bulk, burrow, and cast - for each time interval (Sigma Plot 11.0). 


\section{RESULTS AND DISCUSSION}

\section{Manipulated plots}

Earthworms. During experimental setup in October 2009, eight D- and eight $D+$ plots $(n=8)$ were dug up and earthworms counted and weighed. Average ( \pm s.d.) earthworm population density (ind. $/ \mathrm{m}^{2}$ ) at $\mathrm{PF}$ in the $\mathrm{D}$ - plots was $134 \pm 46$ and $179 \pm$ 51 in the D+plots. Average earthworm population density at WAJ in the D-plots was $109 \pm 24$ and $98 \pm 31$ in the $\mathrm{D}+$ plots. Average ( \pm s.d.) earthworm mass $\left(\mathrm{g} / \mathrm{m}^{2}\right)$ at $\mathrm{PF}$ in the D-plots was $50 \pm 16$ and $67 \pm 9$ in the D+ plots. Average earthworm mass at WAJ in the D-plots was $40 \pm 20$ and $36 \pm 18$ in the $D+$ plots. A t-test showed that there was no significant difference in earthworm count or mass between treatments at either site. An ANOVA showed that there was also no difference in earthworm count or mass between sites.

At the end of the experiment (November, 2010) plots ( $n=5)$ were dug up and sampled again for earthworms. Average ( \pm s.d.) earthworm population density (ind. $/ \mathrm{m}^{2}$ ) at the end of the experiment at PF in the D- plots was $101.5 \pm 52,87.5 \pm 28$ in the D+plots, and $136.1 \pm 34$ in the U plots. Average earthworm population density at WAJ at the end of the experiment was $33.5 \pm 25$ in the D-plots, $25.4 \pm 16$ in the D+ plots, and $34.6 \pm 25$ in the $U$ plots. Average earthworm mass $\left(\mathrm{g} / \mathrm{m}^{2}\right)$ at $P F$ at the end of the experiment was $48.0 \pm 19$ in the D-plots, $64.0 \pm 17$ in the D+plots, and $42.1 \pm$ 18 in the U plots. Average earthworm mass at WAJ at the end of the experiment was $9.5 \pm 6$ in the D-plots, $7.6 \pm 4$ in the D+ plots, and $10.4 \pm 5$ in the U plots. Results of Students t-tests show that there was no significant difference in count or mass between treatments within each site. Furthermore, an ANOVA showed that there was also no 
difference in average earthworm count or biomass between sites. At PF there was a significantly higher earthworm population density in the $\mathrm{D}+$ plots at the beginning of the experiment than at the end of the experiment although biomass was not significantly different. At WAJ there was significantly higher earthworm population density and biomass before the experiment in the $\mathrm{D}$ - and $\mathrm{D}+$ plots than after.

Since all of the visible earthworms from the $\mathrm{D}$ - plots were removed prior to the experiment, our results suggest that at $\mathrm{PF}$ earthworms recolonized the $\mathrm{D}$ - plots to a population density similar to what was there prior to removal. By the end of the experiment at PF there was no significant difference in earthworm population density or average earthworm biomass between the $\mathrm{D}$ - and $\mathrm{D}+$ plots. At WAJ, earthworms also recolonized the D- plots but at a population density and average biomass that is significantly lower than those found prior to removal. However, earthworm population density and average biomass also decreased in the $\mathrm{D}+$ plots, resulting in no significant difference in earthworm population density or earthworm biomass between D- and D+ plots at the end of the experiment.

It is difficult to quantify the timing or recolonization rate of earthworms into the D- plots. The mesh fence that was used to prevent earthworm migration into Dplots was in place and was in good working order at the end of the experiment. It is therefore not likely that earthworms recolonized from outside the plots by horizontal movement. It is more likely that earthworm cocoons were present in the soil at the beginning of the experiment, thus providing a source for earthworms in plots that were intended to have none. 
At PF the mean ( \pm s.d.) volumetric water content $\left(\mathrm{m}^{3} / \mathrm{m}^{3}\right)$ (Fig. 2) ranged from $0.027 \pm 0.01(8 / 14 / 10)$ to $0.342 \pm 0.03(6 / 13 / 10)$ in the U plots, $0.008 \pm 0.02(7 / 13 / 10)$ to $0.400 \pm 0.06(6 / 13 / 10)$ in the $\mathrm{D}$ - plots, and $0.025 \pm 0.01(8 / 14 / 10)$ to $0.382 \pm 0.04$ $(6 / 13 / 10)$ in the D+ plots. At WAJ the volumetric water content ranged from $0.136 \pm$ $0.04(8 / 15 / 10)$ to $0.391 \pm 0.06(10 / 6 / 10)$ in the $U$ plots, $0.153 \pm 0.05(8 / 15 / 10)$ to 0.362 $\pm 0.08(10 / 6 / 10)$ in the D-plots, and $0.150 \pm 0.04(8 / 15 / 10)$ to $0.401 \pm 0.08(10 / 6 / 10)$ in the $\mathrm{D}+$ plots.

In general, soil moisture content from all plots followed similar trends. As expected soil moisture was highest after storm events and was lowest in the afternoon on the hottest summer months (July and August), after exposure to the sun during the day. There were no significant differences in soil moisture content between treatments within each site (as determined by a one-way ANOVA). Furthermore, there was no relation between soil moisture and methane flux found for any treatment at either site.

At $\mathrm{PF}$, mean ( \pm s.d.) soil temperature $\left({ }^{\circ} \mathrm{C}\right)$ ranged from $8.0 \pm 1(5 / 13 / 10)$ to $31.2 \pm 1(7 / 12 / 10)$ in the $U$ plots, $7.2 \pm 1(5 / 13 / 10)$ to $31.0 \pm 1(7 / 12 / 10)$ in the Dplots, and $7.6 \pm 1(5 / 13 / 10)$ to $31.2 \pm 1(7 / 12 / 10)$ in the D+ plots. At WAJ, soil temperature ranged from $7.0 \pm 1(5 / 12 / 10)$ to $25.2 \pm 1(7 / 13 / 10)$ in the $U$ plots, $6.8 \pm 1$ $(5 / 12 / 10)$ to $24.7 \pm 1(7 / 13 / 10)$ in the D-plots, and $6.9 \pm 1(5 / 12 / 10)$ to $24.7 \pm 1$ $(7 / 13 / 10)$ in the D+ plots. Results of a one-way ANOVA showed no differences in temperature between treatments at either site. Further analysis also showed no relationship between soil temperature and methane flux for any treatment at either site. 
Figure 2. Mean methane flux $(n=4)$, soil temperature $(n=3)$, and volumetric water content $(n=3)$ of manipulated plots at Peckham Farm as a function of time. U, undisturbed plots; D-, disturbed plots with earthworms removed; D+, disturbed plots with earthworms present. Bars represent one standard deviation. Water content and temperature sensors placed $10 \mathrm{~cm}$ below soil surface.

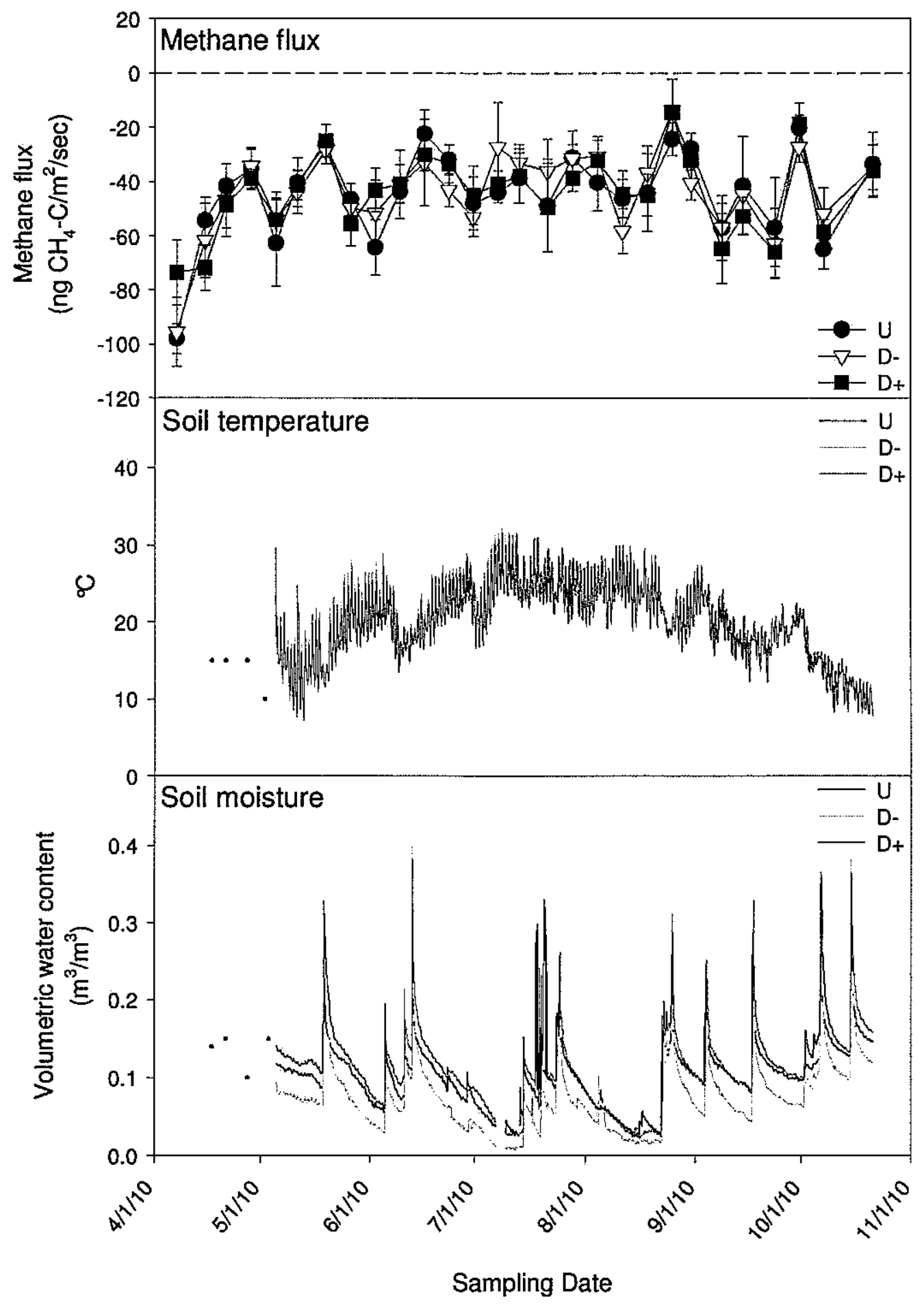


Methane flux. Mean ( \pm s.d.) methane flux (ng $\mathrm{CH}_{4}-\mathrm{C} / \mathrm{m}^{2} / \mathrm{sec}$ ) (negative values indicate net consumption; positive values indicate net production) in the $\mathrm{U}$ treatment manipulated plots ranged from $-98 \pm 6$ to $-20 \pm 9$ at PF; and $-42 \pm 7$ to $2 \pm 5$ at WAJ (Fig. 2). Mean methane flux in the D- treatment manipulated plots ranged from $-95 \pm 13$ to $-14 \pm 11$ at $P F$ and $-46 \pm 11$ to $-4 \pm 4$ at WAJ. Mean methane flux in the $\mathrm{D}+$ treatment plots ranged from $-73 \pm 12$ to $-14 \pm 12$ at $\mathrm{PF}$ and $-38 \pm 7$ to $-8 \pm 5$ at WAJ (Fig. 3). These values are within the range of those reported by Glatzel and Stahr (2001), who found a range of methane fluxes from -55.5 to $361.1 \mathrm{ng} \mathrm{CH}_{4}{ }^{-}$ $\mathrm{C} / \mathrm{m}^{2} / \mathrm{sec}$ in a study examining the effects of fertilizer on methane flux in a temperate grassland in southern Germany.

A two-way repeated measures ANOVA showed no overall difference in methane flux among the three treatments at PF. On two out of a total 27 sampling dates there was significantly higher methane consumption (more negative flux) in Dthan in D+ treatments (Table 4). Furthermore, on three out of 27 sampling dates Dhad significantly lower methane consumption than the D+treatment. These contradictory results do not support our hypothesis that the D- treatment would have significantly lower methane consumption than the D+treatment. By contrast, there was a significant overall difference in methane flux among treatments at the WAJ site (Fig. 3). Furthermore, there was significantly higher net methane consumption in Dthan in D+treatments on seven dates out of a total of 26 sampling days (Table 5). These results support the hypothesis that plots with earthworms removed (D-) should have higher net methane consumption than plots with earthworms (D+). 
Figure 3. Mean methane flux $(n=4)$, soil temperature $(n=3)$, and volumetric water content $(n=3)$ of manipulated plots at $W$. Alton Jones as a function of time. $U$, undisturbed plots; D-, disturbed plots with earthworms removed; D+, disturbed plots with earthworms present. Bars represent one standard deviation. Water content and temperature sensors placed $10 \mathrm{~cm}$ below soil surface.

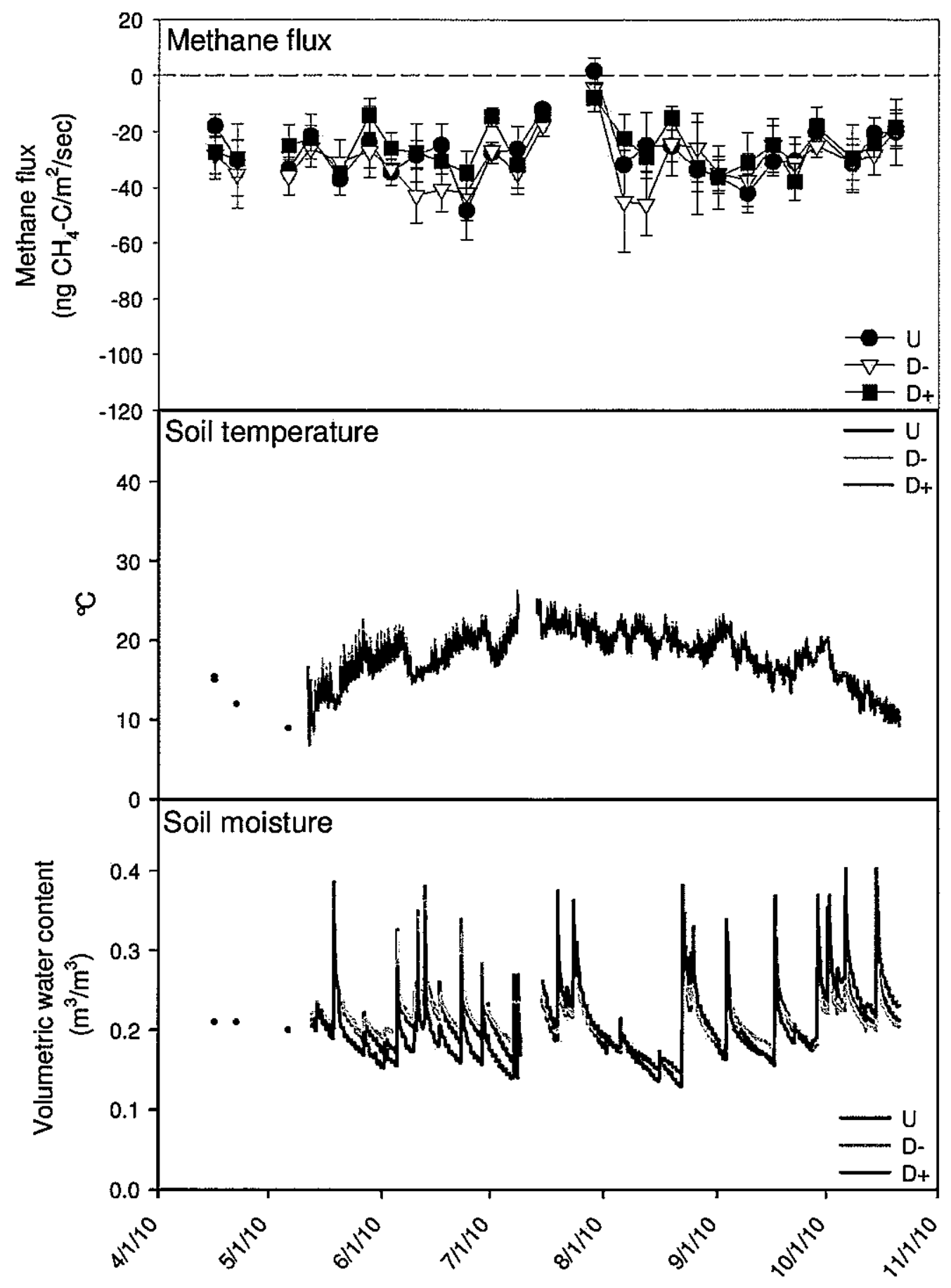

Sampling date 
Table 4. Significant differences in methane flux $(\mathrm{p} \leq 0.05)$ among treatments within date at Peckham Farm identified using two-way repeated measures.

\begin{tabular}{|c|c|c|c|}
\hline Date & Treatment 1 & Treatment 2 & $\begin{array}{c}\text { Significant } \\
\text { difference direction }\end{array}$ \\
\hline \multirow[t]{3}{*}{$4 / 15 / 2010$} & D- & $\overline{D+}$ & - \\
\hline & D- & $\mathrm{U}$ & - \\
\hline & D+ & $\mathrm{U}$ & $<$ \\
\hline \multirow[t]{3}{*}{$4 / 21 / 2010$} & D- & $\mathrm{D}+$ & - \\
\hline & D- & $\mathrm{U}$ & $>$ \\
\hline & $\mathrm{D}+$ & $\mathrm{U}$ & $>$ \\
\hline \multirow[t]{3}{*}{$4 / 28 / 2010$} & D- & $\mathrm{D}+$ & - \\
\hline & D- & $\mathrm{U}$ & - \\
\hline & $\mathrm{D}+$ & $\mathrm{U}$ & - \\
\hline \multirow[t]{3}{*}{$5 / 5 / 2010$} & D- & $\mathrm{D}+$ & - \\
\hline & D- & U & - \\
\hline & D+ & $\mathrm{U}$ & - \\
\hline \multirow[t]{3}{*}{$5 / 11 / 2010$} & D- & $\mathrm{D}+$ & - \\
\hline & D. & $\mathrm{U}$ & - \\
\hline & D+ & $\mathrm{U}$ & - \\
\hline \multirow[t]{3}{*}{$5 / 19 / 2010$} & D- & $\mathrm{D}+$ & - \\
\hline & D- & $U$ & - \\
\hline & $\mathrm{D}+$ & $\mathrm{U}$ & - \\
\hline \multirow[t]{3}{*}{$5 / 26 / 2010$} & D- & $\mathrm{D}+$ & - \\
\hline & D- & $\mathrm{U}$ & - \\
\hline & $\mathrm{D}+$ & $\mathrm{U}$ & $>$ \\
\hline \multirow[t]{3}{*}{$6 / 2 / 2010$} & D- & $\mathrm{D}+$ & - \\
\hline & D- & $U$ & $<$ \\
\hline & D+ & $\mathrm{U}$ & $<$ \\
\hline \multirow[t]{3}{*}{$6 / 9 / 2010$} & $\overline{D-}$ & $\overline{\mathrm{D}+}$ & - \\
\hline & D- & $\mathrm{U}$ & $<$ \\
\hline & $\mathrm{D}+$ & $\mathrm{U}$ & $<$ \\
\hline \multirow[t]{3}{*}{$6 / 16 / 2010$} & D- & $\mathrm{D}+$ & - \\
\hline & D- & U & $>$ \\
\hline & $\mathrm{D}+$ & $\mathrm{U}$ & - \\
\hline \multirow[t]{3}{*}{$6 / 23 / 2010$} & D- & $\mathrm{D}+$ & $>$ \\
\hline & D- & $\mathrm{U}$ & $<$ \\
\hline & D+ & $\mathrm{U}$ & - \\
\hline \multirow[t]{3}{*}{$6 / 30 / 2010$} & D- & $\mathrm{D}+$ & - \\
\hline & D- & $\mathrm{U}$ & - \\
\hline & D+ & $\mathrm{U}$ & - \\
\hline \multirow[t]{3}{*}{$7 / 7 / 2010$} & D- & $\overline{D+}$ & $<$ \\
\hline & D- & $\mathrm{U}$ & $<$ \\
\hline & D+ & $\mathrm{U}$ & - \\
\hline \multirow[t]{2}{*}{$7 / 13 / 2010$} & D- & $\mathrm{D}+$ & $<$ \\
\hline & D- & $\mathrm{U}$ & - \\
\hline
\end{tabular}




\begin{tabular}{|c|c|c|c|}
\hline & $\mathrm{D}+$ & $\mathrm{U}$ & - \\
\hline \multirow[t]{3}{*}{$7 / 21 / 2010$} & D- & $\mathrm{D}+$ & $<$ \\
\hline & D- & $\mathrm{U}$ & - \\
\hline & $\mathrm{D}+$ & $\mathrm{U}$ & $>$ \\
\hline \multirow[t]{3}{*}{$7 / 28 / 2010$} & D- & $\mathrm{D}+$ & - \\
\hline & $\mathrm{D}-$ & $\mathrm{U}$ & - \\
\hline & $\mathrm{D}+$ & $\mathrm{U}$ & - \\
\hline \multirow[t]{3}{*}{$8 / 4 / 2010$} & D- & $\overline{\mathrm{D}+}$ & 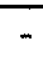 \\
\hline & D- & $\mathrm{U}$ & $<$ \\
\hline & D+ & $\mathrm{U}$ & - \\
\hline \multirow[t]{3}{*}{$8 / 11 / 2010$} & D- & $\mathrm{D}+$ & $>$ \\
\hline & D- & $\mathrm{U}$ & - \\
\hline & D+ & $\mathrm{U}$ & - \\
\hline \multirow[t]{3}{*}{$8 / 18 / 2010$} & $\mathrm{D}$ - & $\mathrm{D}+$ & - \\
\hline & D- & $\mathrm{U}$ & - \\
\hline & $\mathrm{D}+$ & $\mathrm{U}$ & - \\
\hline \multirow[t]{3}{*}{$8 / 24 / 2010$} & D- & $\mathrm{D}+$ & - \\
\hline & D- & $U$ & - \\
\hline & $\mathrm{D}+$ & $U$ & - \\
\hline \multirow[t]{3}{*}{$8 / 30 / 2010$} & D- & $\mathrm{D}+$ & - \\
\hline & D. & $\mathrm{U}$ & - \\
\hline & $\mathrm{D}+$ & $\mathrm{U}$ & - \\
\hline \multirow[t]{3}{*}{$9 / 8 / 2010$} & D- & $\mathrm{D}+$ & - \\
\hline & D- & $\mathrm{U}$ & - \\
\hline & $\mathrm{D}+$ & $\mathrm{U}$ & - \\
\hline \multirow[t]{3}{*}{$9 / 14 / 2010$} & D- & $\mathrm{D}+$ & - \\
\hline & D- & $\mathrm{U}$ & - \\
\hline & $\mathrm{D}+$ & $\mathrm{U}$ & $\geq$ \\
\hline \multirow[t]{3}{*}{$9 / 23 / 2010$} & D- & $\mathrm{D}+$ & - \\
\hline & D- & $U$ & - \\
\hline & $\mathrm{D}+$ & $\mathrm{U}$ & - \\
\hline \multirow[t]{3}{*}{$9 / 30 / 2010$} & D. & $\mathrm{D}+$ & $\sim$ \\
\hline & D- & $\mathrm{U}$ & - \\
\hline & $\mathrm{D}+$ & $\mathrm{U}$ & - \\
\hline \multirow[t]{3}{*}{$10 / 7 / 2010$} & D- & $\mathrm{D}+$ & - \\
\hline & D- & $\mathrm{U}$ & $<$ \\
\hline & $\mathrm{D}+$ & $\mathrm{U}$ & - \\
\hline \multirow[t]{3}{*}{$10 / 21 / 2010$} & D- & $\mathrm{D}+$ & - \\
\hline & D- & $\mathrm{U}$ & - \\
\hline & $\mathrm{D}+$ & $\mathrm{U}$ & - \\
\hline
\end{tabular}


Table 5. Significant differences in methane flux ( $\mathrm{p} \leq 0.05$ ) among treatments within date at W. Alton Jones identified using two-way repeated measures ANOVA.

Significant

Date Treatment 1 $\quad$ Treatment 2 difference direction

\begin{tabular}{|c|c|c|c|}
\hline $4 / 16 / 2010$ & $\begin{array}{l}\text { D- } \\
\text { D- } \\
\text { D+ }\end{array}$ & $\begin{array}{c}\mathrm{D}+ \\
\mathrm{U} \\
\mathrm{U}\end{array}$ & $\begin{array}{l}\overline{-} \\
\overline{-}\end{array}$ \\
\hline \multirow[t]{3}{*}{$4 / 22 / 2010$} & D- & $\mathrm{D}+$ & - \\
\hline & D- & $\mathrm{U}$ & - \\
\hline & $\mathrm{D}+$ & $\mathrm{U}$ & - \\
\hline \multirow{3}{*}{$5 / 6 / 2010$} & D- & $\mathrm{D}+$ & $>$ \\
\hline & D- & $\mathrm{U}$ & - \\
\hline & $\mathrm{D}+$ & $\mathrm{U}$ & - \\
\hline \multirow[t]{3}{*}{$5 / 12 / 2010$} & D- & $\mathrm{D}+$ & - \\
\hline & D- & $\mathrm{U}$ & - \\
\hline & $\mathrm{D}+$ & $\mathrm{U}$ & - \\
\hline \multirow[t]{3}{*}{$5 / 20 / 2010$} & D- & $\mathrm{D}+$ & - \\
\hline & D. & $U$ & - \\
\hline & D+ & $\mathrm{U}$ & - \\
\hline \multirow[t]{3}{*}{$5 / 28 / 2010$} & D- & D+ & $>$ \\
\hline & D- & $\mathrm{U}$ & - \\
\hline & $\mathrm{D}+$ & $\mathrm{U}$ & $<$ \\
\hline \multirow[t]{3}{*}{$6 / 3 / 2010$} & D- & $\mathrm{D}+$ & - \\
\hline & D. & U & - \\
\hline & $\mathrm{D}+$ & $\mathrm{U}$ & - \\
\hline \multirow[t]{3}{*}{$6 / 10 / 2010$} & D- & $\mathrm{D}+$ & $>$ \\
\hline & D- & $\mathrm{U}$ & $<$ \\
\hline & $\mathrm{D}+$ & $\mathrm{U}$ & - \\
\hline \multirow[t]{3}{*}{$6 / 17 / 2010$} & D- & $\mathrm{D}+$ & - \\
\hline & D- & $\mathrm{U}$ & $>$ \\
\hline & $\mathrm{D}+$ & $\mathrm{U}$ & - \\
\hline \multirow[t]{3}{*}{$6 / 24 / 2010$} & D- & $\mathrm{D}+$ & - \\
\hline & D- & $\mathrm{U}$ & - \\
\hline & $\mathrm{D}+$ & $\mathrm{U}$ & $\leq$ \\
\hline \multirow[t]{3}{*}{$7 / 1 / 2010$} & D- & $\mathrm{D}+$ & $>$ \\
\hline & D- & U & - \\
\hline & $\mathrm{D}+$ & U & $<$ \\
\hline \multirow[t]{3}{*}{$7 / 8 / 2010$} & D- & $\mathrm{D}+$ & 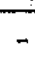 \\
\hline & D- & U & - \\
\hline & D+ & $\mathrm{U}$ & - \\
\hline \multirow[t]{3}{*}{$7 / 15 / 2010$} & D- & $\mathrm{D}+$ & - \\
\hline & D- & $\mathrm{U}$ & - \\
\hline & $\mathrm{D}+$ & $\mathrm{U}$ & - \\
\hline \multirow[t]{2}{*}{$7 / 29 / 2010$} & D- & $\mathrm{D}+$ & - \\
\hline & D- & $\mathrm{U}$ & . \\
\hline
\end{tabular}




\begin{tabular}{|c|c|c|c|}
\hline & $\mathrm{D}+$ & $\mathrm{U}$ & - \\
\hline \multirow[t]{3}{*}{$8 / 6 / 2010$} & D- & $\mathrm{D}+$ & $>$ \\
\hline & D- & $\mathrm{U}$ & $<$ \\
\hline & $\mathrm{D}+$ & $\mathrm{U}$ & - \\
\hline \multirow[t]{3}{*}{$8 / 12 / 2010$} & D. & $\mathrm{D}+$ & $>$ \\
\hline & D- & $\mathrm{U}$ & $>$ \\
\hline & $\mathrm{D}+$ & $\mathrm{U}$ & - \\
\hline \multirow[t]{3}{*}{$8 / 19 / 2010$} & D- & $\mathrm{D}+$ & $>$ \\
\hline & D- & $\mathrm{U}$ & - \\
\hline & $\mathrm{D}+$ & U & - \\
\hline \multirow[t]{3}{*}{$8 / 26 / 2010$} & D- & $\mathrm{D}+$ & - \\
\hline & D- & U & - \\
\hline & $\mathrm{D}+$ & U & - \\
\hline \multirow[t]{3}{*}{$9 / 1 / 2010$} & D- & $\mathrm{D}+$ & - \\
\hline & D- & $\mathrm{U}$ & - \\
\hline & $\mathrm{D}+$ & $\mathrm{U}$ & - \\
\hline \multirow[t]{3}{*}{$9 / 9 / 2010$} & $\mathrm{D}$ & $\mathrm{D}+$ & - \\
\hline & D- & $\mathrm{U}$ & - \\
\hline & $\mathrm{D}+$ & $\mathrm{U}$ & - \\
\hline \multirow[t]{3}{*}{$9 / 16 / 2010$} & D- & $\mathrm{D}+$ & - \\
\hline & D- & $\mathrm{U}$ & - \\
\hline & $\mathrm{D}+$ & $\mathrm{U}$ & - \\
\hline \multirow[t]{3}{*}{$9 / 22 / 2010$} & $\mathrm{D}$ & $\mathrm{D}+$ & 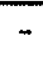 \\
\hline & D- & $\mathrm{U}$ & - \\
\hline & $\mathrm{D}+$ & $\mathrm{U}$ & - \\
\hline \multirow[t]{3}{*}{$9 / 28 / 2010$} & D- & $\mathrm{D}+$ & - \\
\hline & D- & $\mathrm{U}$ & - \\
\hline & $\mathrm{D}+$ & $\mathrm{U}$ & - \\
\hline \multirow[t]{3}{*}{$10 / 8 / 2010$} & D- & $\mathrm{D}+$ & - \\
\hline & $\mathrm{D}-$ & $\mathrm{U}$ & - \\
\hline & $\mathrm{D}+$ & $\mathrm{U}$ & - \\
\hline \multirow[t]{3}{*}{$10 / 14 / 2010$} & D- & $\mathrm{D}+$ & - \\
\hline & D- & $\mathrm{U}$ & - \\
\hline & $\mathrm{D}+$ & $\mathrm{U}$ & - \\
\hline \multirow[t]{3}{*}{$10 / 20 / 2010$} & D- & $\mathrm{D}+$ & - \\
\hline & D- & $\mathrm{U}$ & - \\
\hline & $\mathrm{D}+$ & $\mathrm{U}$ & - \\
\hline
\end{tabular}


At WAJ significant differences in methane flux among treatments were observed only between 6 May and 19 August, with no differences observed subsequently. Similarly, differences in methane flux among treatments at PF were all observed prior to 11 August. These results suggest that there may have been a change in conditions at both sites that lead to a diminished effect by earthworms in mid-August. The effects of earthworms on methane flux may depend on factors such as temperature, inorganic nitrogen species and concentration, and soil moisture, all of which have been found to play a role in methane flux (Parkin and Berry, 1999; van den Pol-van Dasselaar et al., 1998).

As stated previously, a one-way repeated measures ANOVA showed no overall differences among treatments in soil temperature or moisture at either site (Fig. 2 and 3). Soil moisture in the D-treatment at PF, although not significantly different, did trend lower than D+ and $U$ treatments on most days (Fig. 2). This difference may be responsible for some of the effects observed; however, this is not likely, since this trend was observed throughout the experiment and not only before August. Another explanation for treatment differences observed exclusively before August involves earthworm recolonization of plots. At the end of the experiment (21 October 2010), plots $(n=5)$ were destructively sampled to determine earthworm population densities, biomass, and species composition. Results of a one-way ANOVA showed that there were no significant differences found in any of these earthworm parameters at Peckham Farm or W. Alton Jones (Fig. 4 and 5). At the beginning of the experiment, D- plots had all earthworms found in the soil removed and D+ plots had earthworms removed and a known amount returned to the plots. Some time during the 
experimental period earthworm counts in the D-plots returned to levels that were not significantly different from $\mathrm{D}+$ or the $\mathrm{U}$ plots (Fig. 5). Some earthworms, such as $L$. rubellus, can travel up to 11 meters per year (Klok et al., 2006). However, since mesh screens were still in place around the plots at the end of the experiment, it seems more likely that population recovery in D- plots was due to hatching of residual cocoons in the soil. Earthworm cocoons hatch mostly in the spring and summer months (Edwards and Bohlen, 1996). In addition, it takes months for juvenile earthworms to reach maturity; for example, it takes $L$. rubellus an average of 36 weeks to reach maturity (Edwards and Bohlen, 1996). It seems reasonable to assume that the earthworms in D- plots originated from cocoons and were in early life stages for the majority of the experimental period. If the absence of earthworms affects methane flux, then these effects would be more apparent before August, when presumably there was a difference in population density between treatments. Furthermore, these differences once earthworm population density was no longer different among treatments.

The reasons for the presence of treatment differences in methane flux at WAJ and not at PF may involve differences in microbial community composition. The methanogenic community may be more active in WAJ soil and/or grow faster when anaerobic microsites are created by soil compaction through burrowing and feeding activity. In addition, soil with a more readily available source of acetate favors the faster-growing acetotrophic Methanosarcina spp. which, in addition to acetate, can use other methylated compounds, as well as $\mathrm{CO}_{2}$ and $\mathrm{H}_{2}$, as substrates for $\mathrm{CH}_{4}$ production 
Figure 4. Mean initial (October 2009, $\mathrm{n}=8$ ) and final (November 2010, $\mathrm{n}=5$ ) earthworm population density and biomass from the manipulated plots at Peckham Farm. U, undisturbed plots; D-, disturbed plots with earthworms removed; D+, disturbed plots with earthworms present. Bars represent one standard deviation.

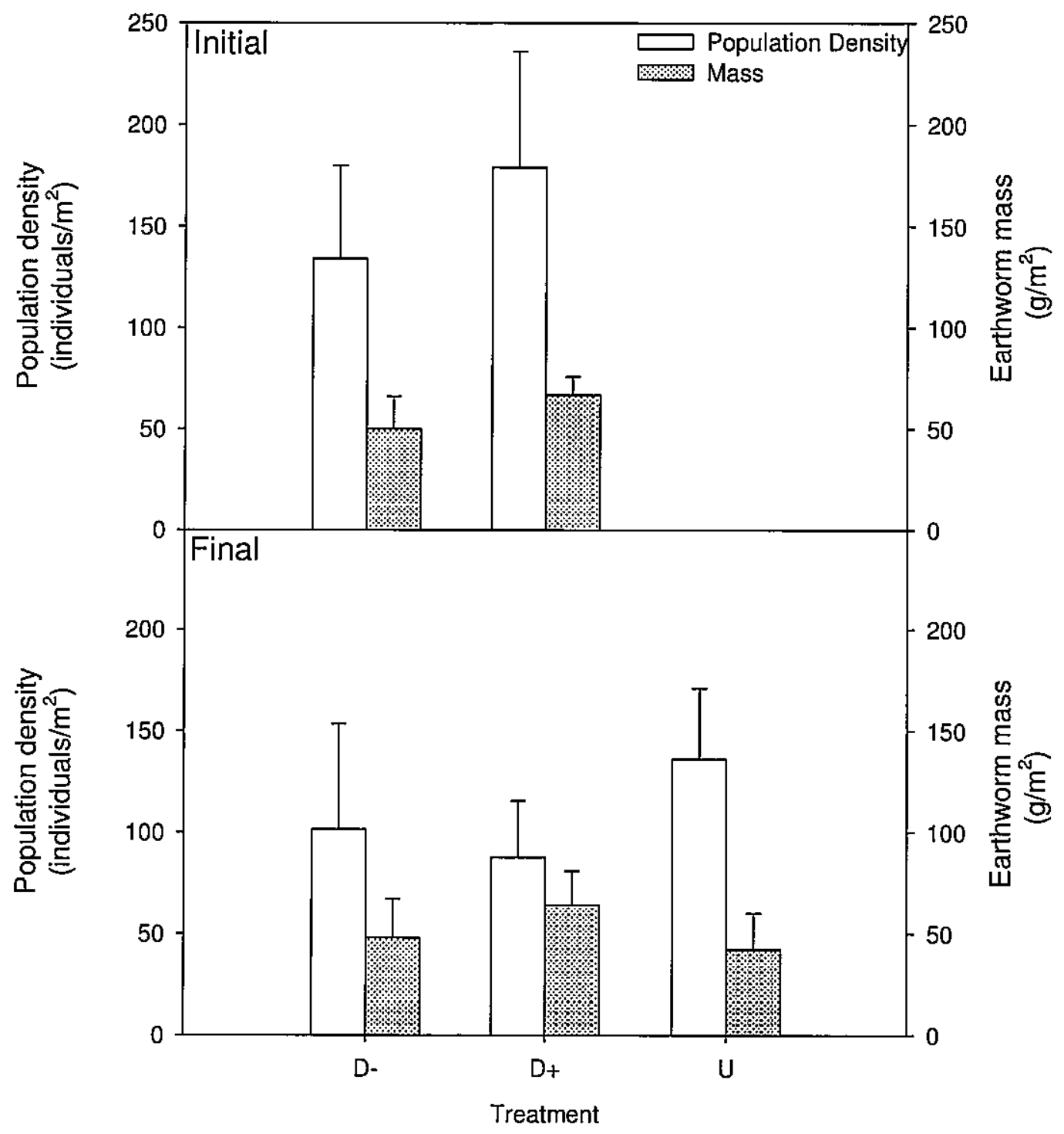


Figure 5. Mean initial (October 2009, $n=8$ ) and final (November 2010, $n=5$ ) earthworm population density and biomass from the manipulated plots at $\mathrm{W}$. Alton Jones. U, undisturbed plots; D-, disturbed plots with earthworms removed; D+, disturbed plots with earthworms present. Bars represent one standard deviation.

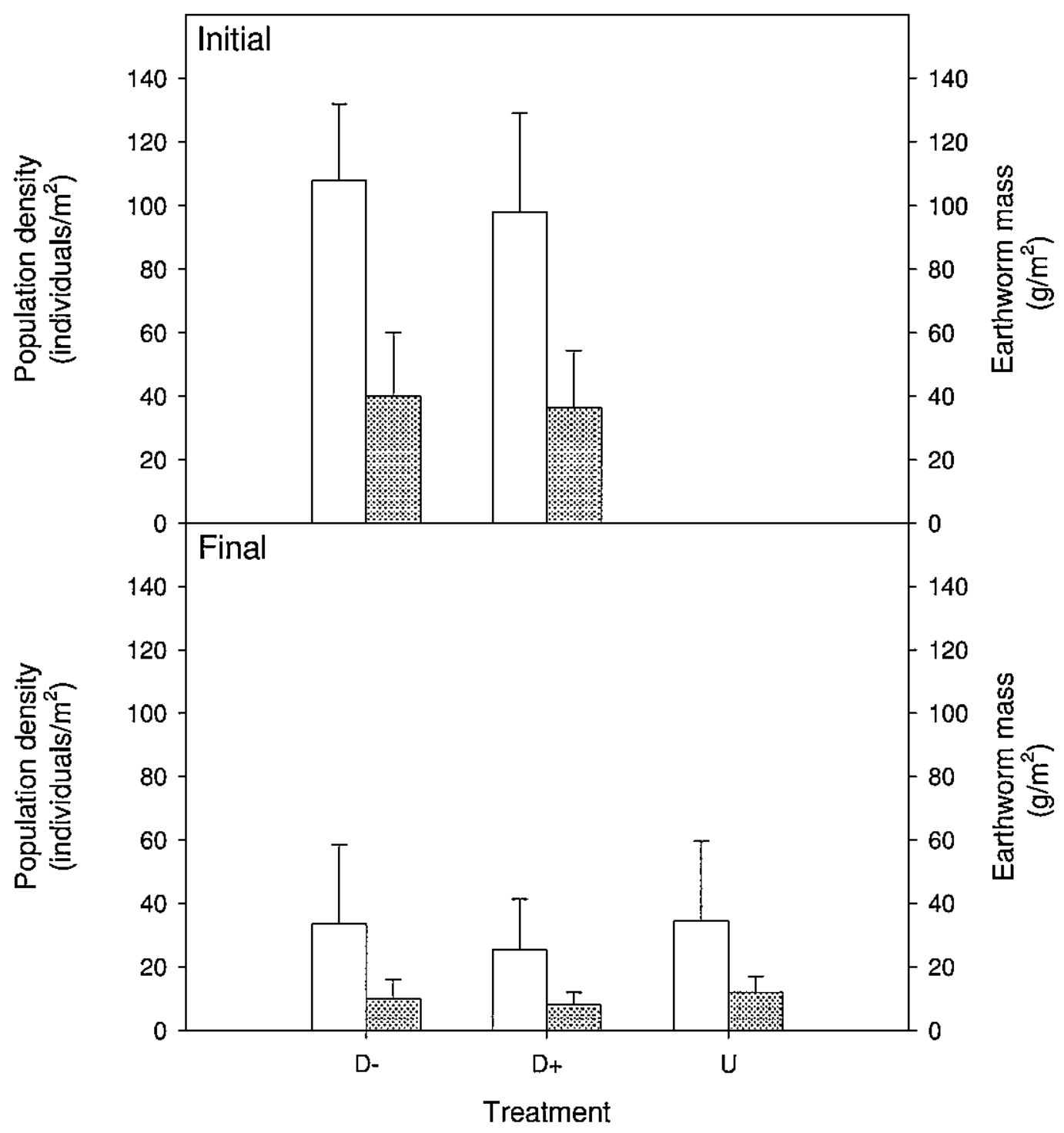


(Zinder, 1993). In contrast, soil with lower levels of acetate favors the slow-growing Methanothrix spp. (Zinder, 1993). Evidence of redoximorphic features at around 74 $\mathrm{cm}$ at WAJ compared to $99 \mathrm{~cm}$ at PF and generally higher soil moisture levels at WAJ indicate that soil at WAJ may be more frequently saturated (Tables 2 and 3). This could mean that WAJ soil may be able to support a larger, more active community of acetogenic bacteria, obligate anaerobes that can survive periods of aerobiosis and are active in oxic soil, and therefore maintain a higher concentration of the methane precursor acetate in soil (Wagner et al., 1996).

A two-way repeated measures ANOVA showed no overall difference between $D+$ treatment and $U$ treatment at PF or WAJ (Fig. 2 and 3). This supports the assumption in our experimental design that removal and return of earthworms, and insertion of mesh fence to mitigate earthworm migration would not impact methane flux. Thus, we can assume that differences found between $\mathrm{D}+$ and $\mathrm{D}$ - plots are due to differences in earthworm communities. In some instances D- or D+ treatments had significantly higher or lower net methane consumption than $\mathrm{U}$ treatments. At PF, on six sampling days methane flux in the $\mathrm{D}+$ plots was significantly different than the $\mathrm{U}$ plots. At WAJ, only two sampling days had methane flux in the D+ plots being significantly different than the $\mathrm{U}$ plots. These differences may be a result of soil disturbance during plot creation, the mesh fencing, or other unknown factors.

Diurnal patterns. An experiment was conducted to assess the patterns of methane flux in the manipulated plots at different times of day. Methane flux measurements were made at 6:00,12:00, and 16:00 h on 30 August 2010 at PF and 1 September 2010 at WAJ. A one-way ANOVA with a Holm-Sidak pairwise multiple 
comparison showed that at 6:00 the methane flux was significantly lower than at 12:00 and 16:00 for all treatments at PF. The $12: 00$ and 16:00 flux values were not different form each other for all treatments (Fig. 6). There were also no differences found between treatments at each time. In addition, there was no significant difference in soil temperature or moisture among sampling times (Fig. 6).

Results were similar at WAJ, with the 6:00 methane flux values significantly lower than the 16:00 values for all treatments (Fig. 7). However, the 6:00 value was significantly lower than the $12: 00$ in $\mathrm{U}$ and $\mathrm{D}+$ treatments, but not in the $\mathrm{D}$ treatments. There were no differences in flux among treatments at 12:00 or at 16:00. In addition, there was no significant difference in soil temperature or moisture among sampling times (Fig. 7). In a similar study of diurnal patterns of methane flux conducted in a dry meadow by Koch et al. (2007), methane flux was recorded every 6 $\mathrm{h}$ over a 24-h period on 11 occasions. Differences in flux at different times of the day were observed, however, there was no distinct temporal pattern. The authors identified temperature and water filled pore space (WFPS) to be important factors in controlling differences (Koch et al., 2007).

The significant increase in net methane consumption at 6:00 may be explained by a decrease in microbial activity over time, most likely due to changes in temperature and moisture of soil closest to the surface. As the soil warms and dries to soil moisture levels below the optimum level for these aerobes, there may be a less active community of methane oxidizers. Although we did not observe significant differences in soil temperature and moisture at a depth of $10 \mathrm{~cm}$, there was a trend 
Figure 6. Methane flux $(n=4)$, soil moisture $(n=3)$ and soil temperature $(n=3)$ at 6:00, 12:00, and 16:00 h on 30 August 2010 at Peckham Farm for D- (earthworms removed), D+ (earthworms and returned), and U (undisturbed) treatments. Bars represent one standard deviation. Water content and temperature sensors placed 10 $\mathrm{cm}$ below soil surface.

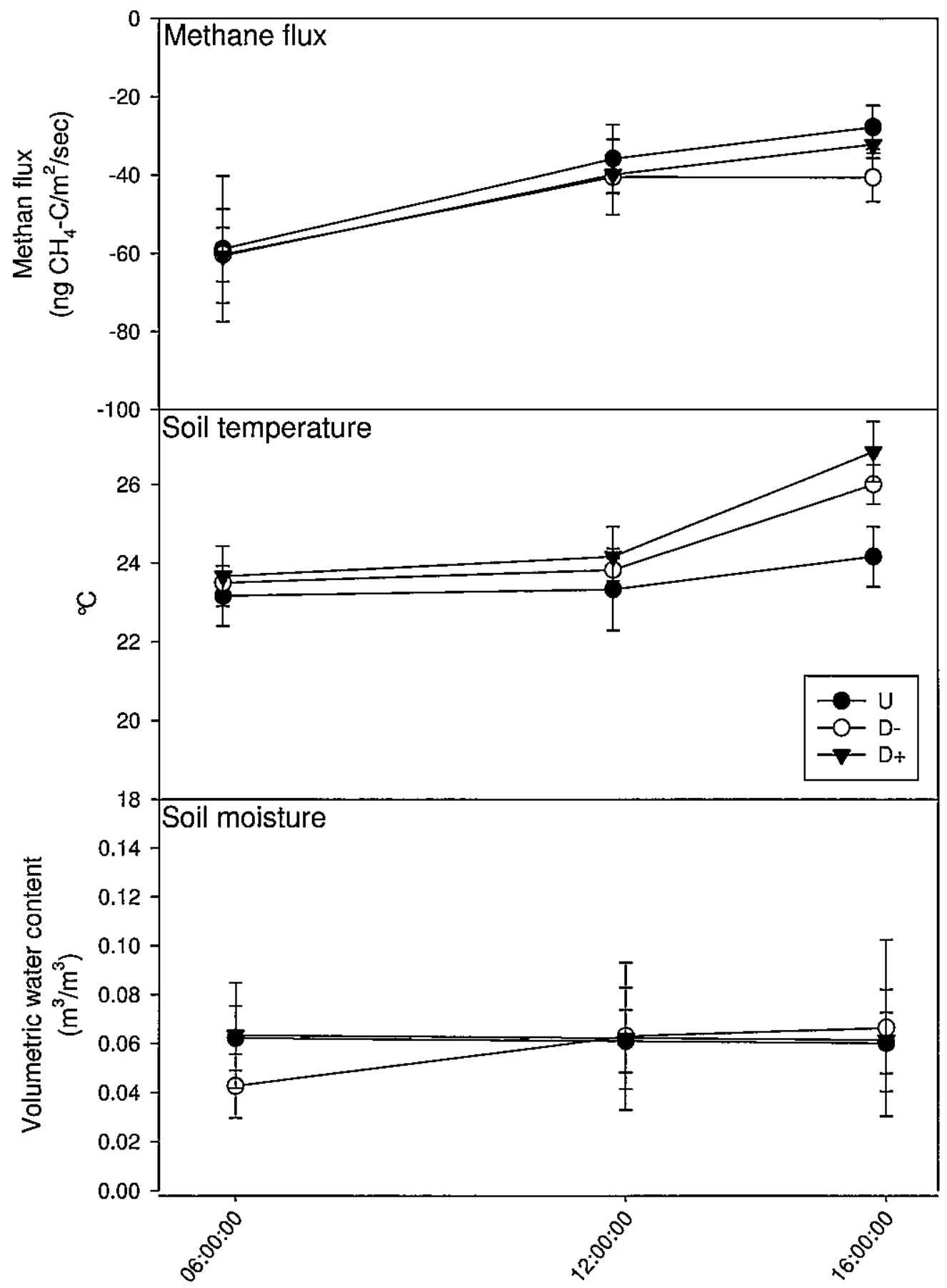

Sampling time 
Figure 7. Methane flux $(n=4)$, soil moisture $(n=3)$ and soil temperature $(n=3)$ at $6: 00$, 12:00, and 16:00 h on 30 August 2010 at W. Alton Jones for D- (earthworms removed), D+ (earthworms and returned), and $\mathrm{U}$ (undisturbed) treatments. Bars represent one standard deviation. Water content and temperature sensors placed 10 $\mathrm{cm}$ below soil surface.

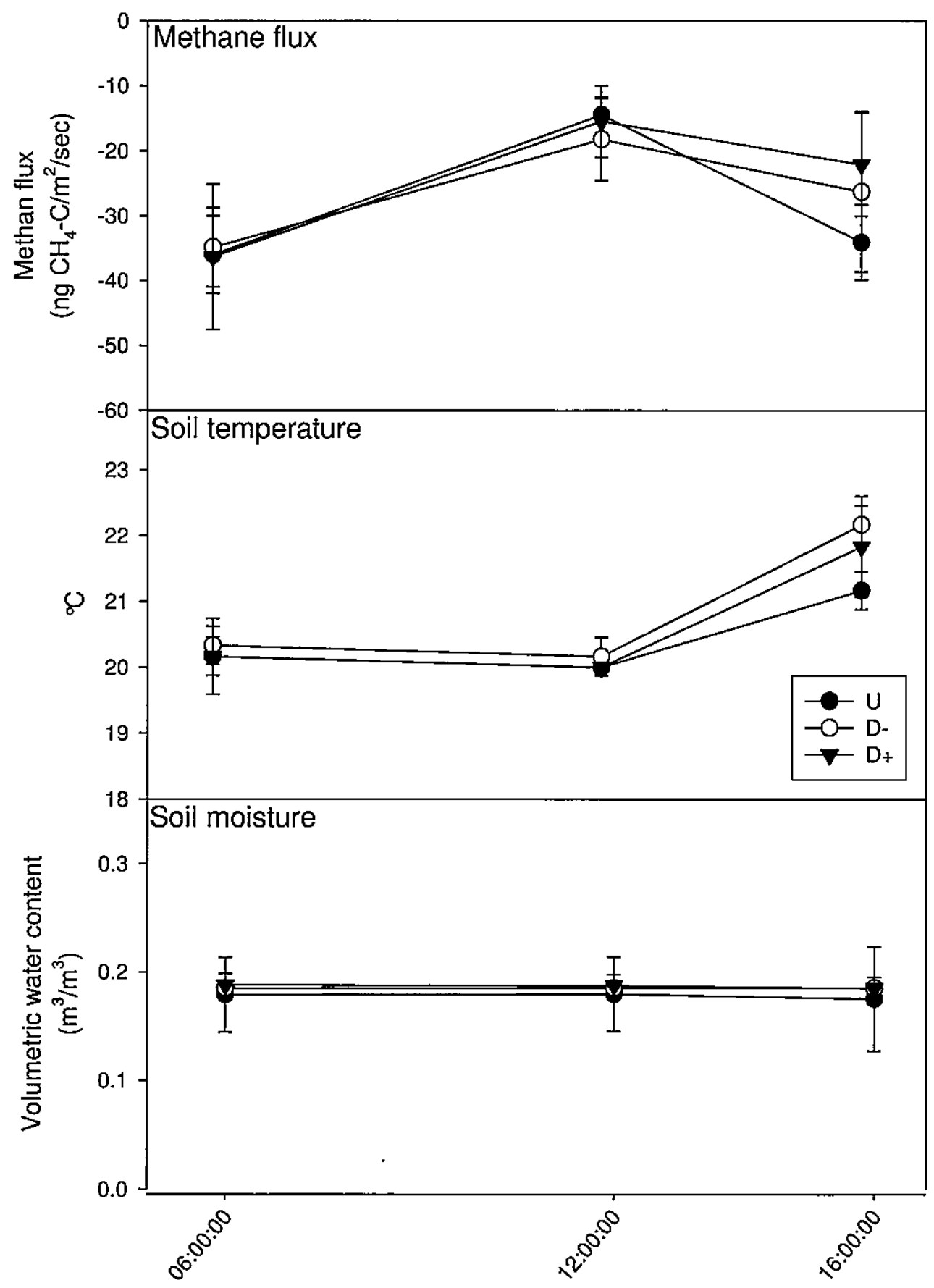

Sampling time 
toward higher temperature as the day goes on. There may have been larger differences closer to the surface. In a separate set of experiments using soil from both sites, we found that potential methane oxidation rates for both soils were highest at 20\% WFPS. Soil closest to the surface may have had moisture levels near 20\% WFPS at 6:00, which decreased with prolonged exposure to sunlight and increased transpiration. Soil moisture data shows that WFPS at PF was well below the optimum for methane oxidation for all treatments and sampling times (Table 6). At WAJ, WFPS was close to the optimum of $20 \%$ for all treatments and sampling times (Table 7). The differences in flux may thus be due to a decrease in methane oxidation, rather than an increase in methanogenesis at least at PF. There may also have been a decrease in methanogenesis near the soil surface. As soil moisture decreases over time through evaporation and transpiration, fewer areas remain with conditions that support methanogenesis.

Table 6. Mean WFPS ( $n=3)$ at $6: 00,12: 00$, and $16: 00 \mathrm{~h}$ on 30 August 2010 at W. Alton Jones for D- (earthworms removed), D+ (earthworms and returned), and U (undisturbed) treatments. Bars represent one standard deviation. Water content sensors placed $10 \mathrm{~cm}$ below soil surface.

\begin{tabular}{cccc}
\hline Treatment & $\mathbf{6 : 0 0}$ & $\mathbf{1 2 : 0 0}$ & $\mathbf{1 6 : 0 0}$ \\
\hline \hline D+ & $7.3 \%$ & $7.3 \%$ & $6.9 \%$ \\
D- & $5.1 \%$ & $7.1 \%$ & $7.4 \%$ \\
U & $7.1 \%$ & $6.9 \%$ & $6.7 \%$ \\
\hline
\end{tabular}


Table 7. Mean WFPS ( $n=3)$ at $6: 00,12: 00$, and $16: 00 \mathrm{~h}$ on 1 September 2010 at Peckham farm for D- (earthworms removed), D+ (earthworms and returned), and U (undisturbed) treatments. Bars represent one standard deviation. Water content sensors placed $10 \mathrm{~cm}$ below soil surface.

\begin{tabular}{cccc}
\hline Treatment & $\mathbf{6 : 0 0}$ & $\mathbf{1 2 : 0 0}$ & $\mathbf{1 6 : 0 0}$ \\
\hline \hline D+ & $23.9 \%$ & $23.3 \%$ & $22.7 \%$ \\
D- & $23.3 \%$ & $22.7 \%$ & $22.7 \%$ \\
U & $22.7 \%$ & $22.0 \%$ & $21.4 \%$ \\
\hline
\end{tabular}

\section{Supplemental Plots}

Purpose. The supplemental plots experiment was designed to determine if there is a relationship between earthworms and methane flux, as well as other soil properties. Earthworm parameters, including population density, biomass, ecological group, and life stage, as well as soil properties, including $\mathrm{pH}$, organic matter content, inorganic nitrogen, and soil temperature and moisture, were determined from each plot after each methane flux sampling.

Earthworms. Population density (ind. $/ \mathrm{m}^{2}$ ) of earthworms over the experimental period ranged from 10 on 19 August to 103 on 7 October at PF, and from 36 on 14 October to 132 on 17 June at WAJ (Fig. 8 and 9). Earthworm population density was lowest in August at both sites, possibly the result of lower soil temperature and moisture (Fig. 10 and 11). Soil temperature was highest, and moisture lowest, in August at both sites. Earthworm activity generally decreases under dry and hot conditions (Edwards, 2004). Earthworm population density will be lower as anecic earthworms burrow deep into the soil - below the $30 \mathrm{~cm}$ sampling depth - to avoid hot and dry conditions. Lumbricus rubellus was the most commonly 
Figure 8. Earthworm population density by ecological group and proportion of adult to juvenile earthworms in the supplemental plots $(n=7)$ at Peckham Farm.

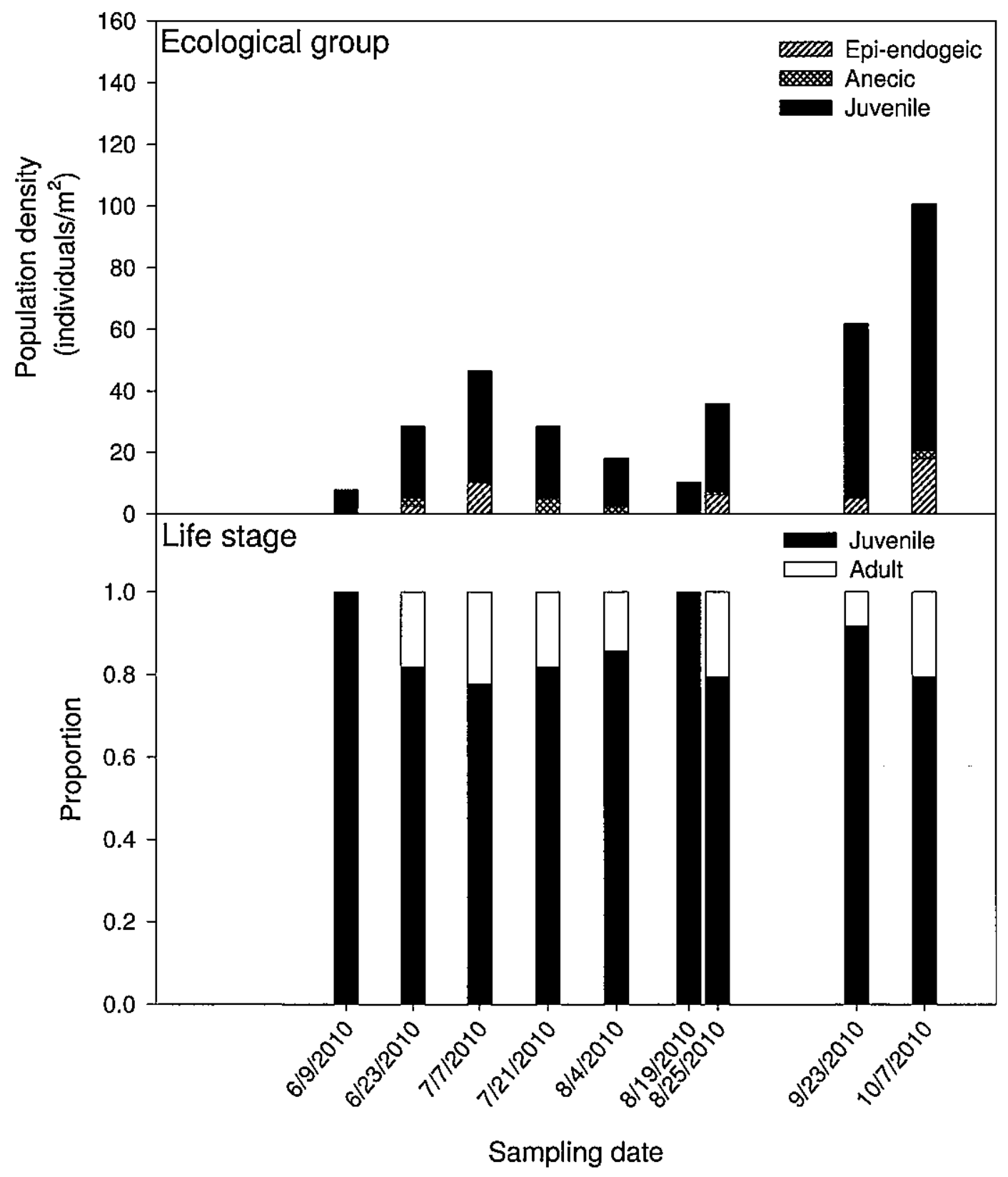


Figure 9. Earthworm population density by ecological group and proportion of adult to juvenile earthworms in the supplemental plots $(n=7)$ at W. Alton Jones.

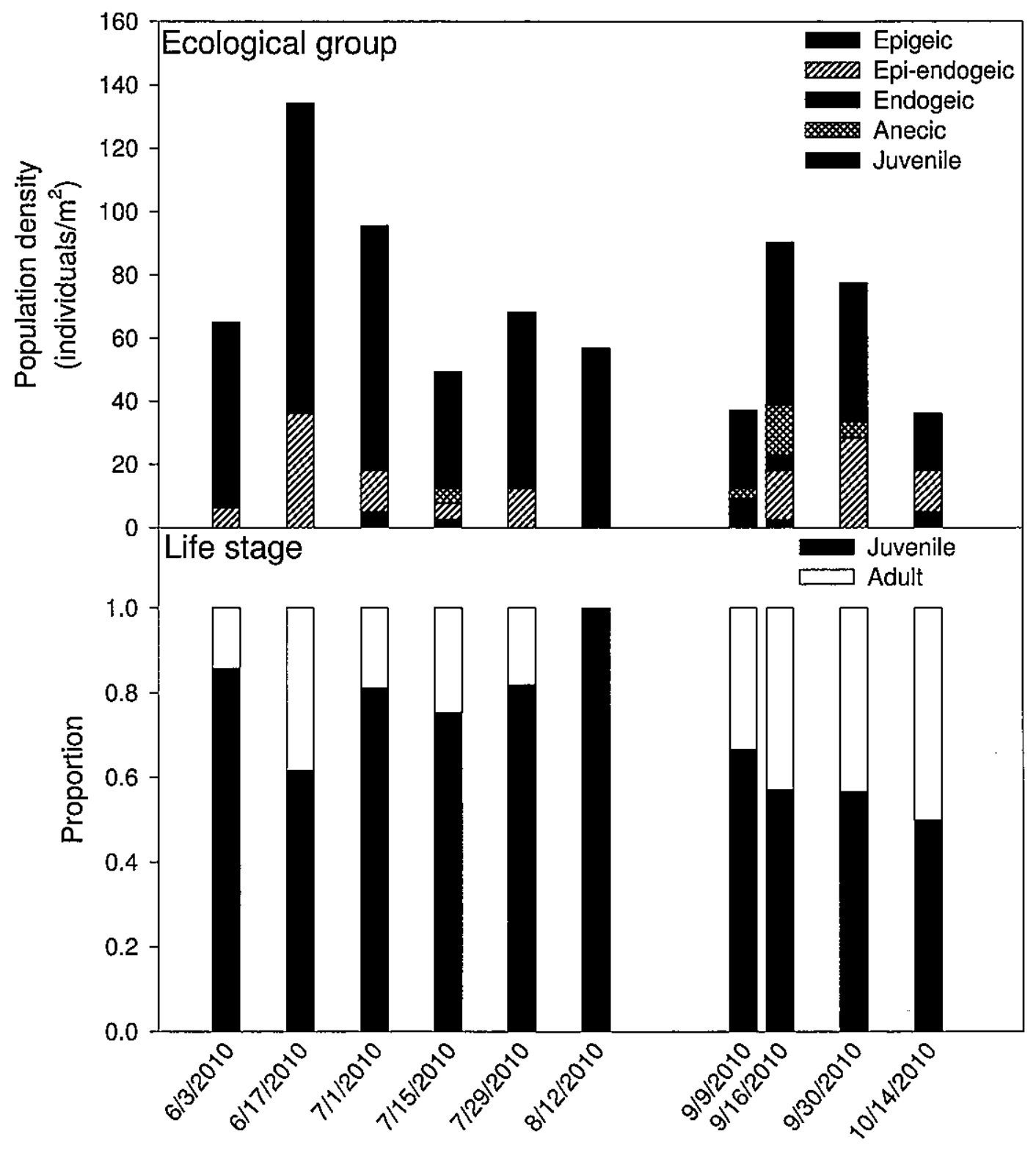

Sampling date 
Figure 10. Mean $(\mathrm{n}=7)$ methane flux, soil moisture, and soil temperature at Peckham Farm for supplementary plots. Bars represent one standard deviation. Water content and temperature data recorded $10 \mathrm{~cm}$ below soil surface.

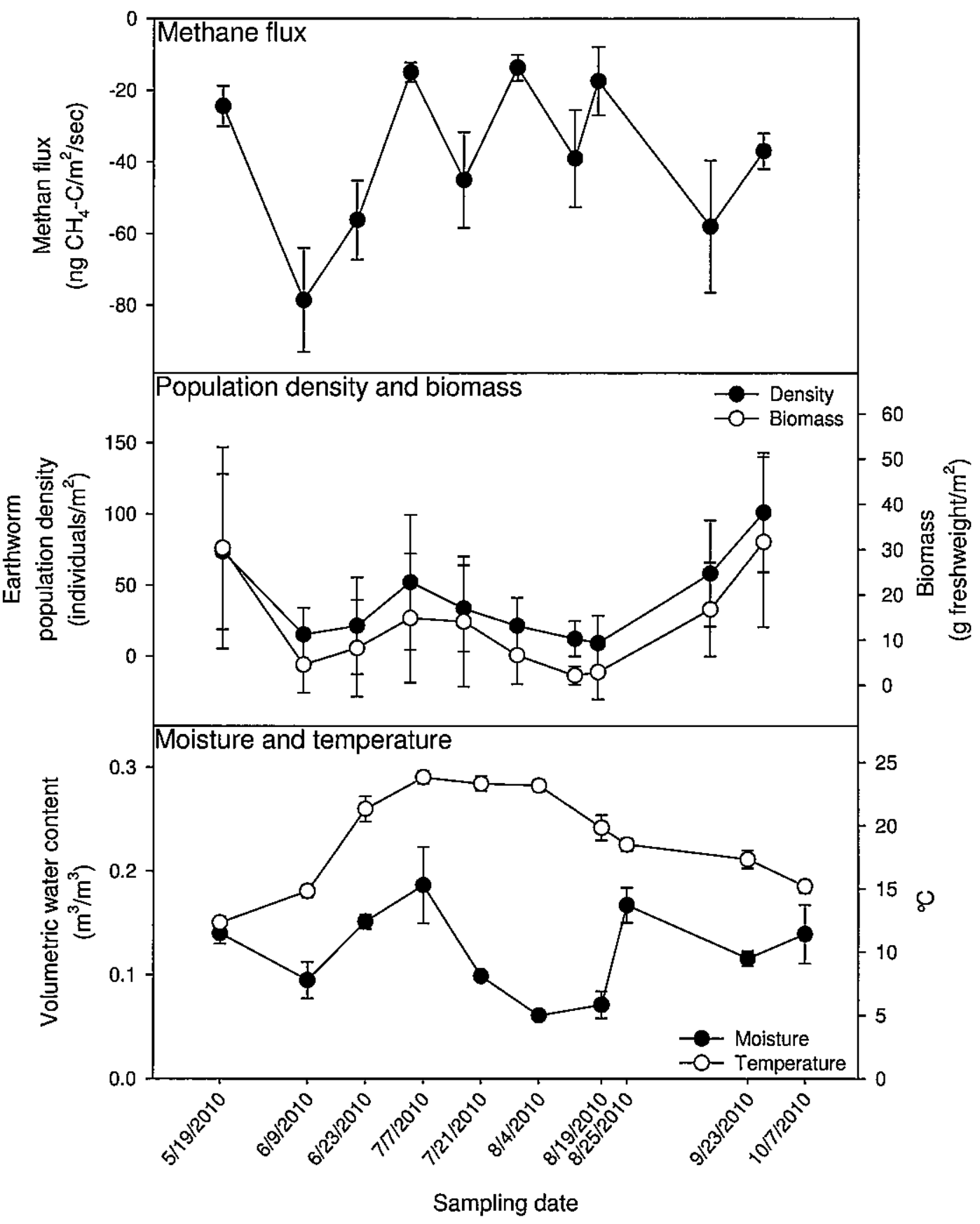


Figure 11. Mean $(\mathrm{n}=7)$ methane flux, soil moisture, and soil temperature for $\mathrm{W}$. Alton Jones supplementary plots. Bars represent one standard deviation. Water content and temperature data recorded $10 \mathrm{~cm}$ below soil surface.

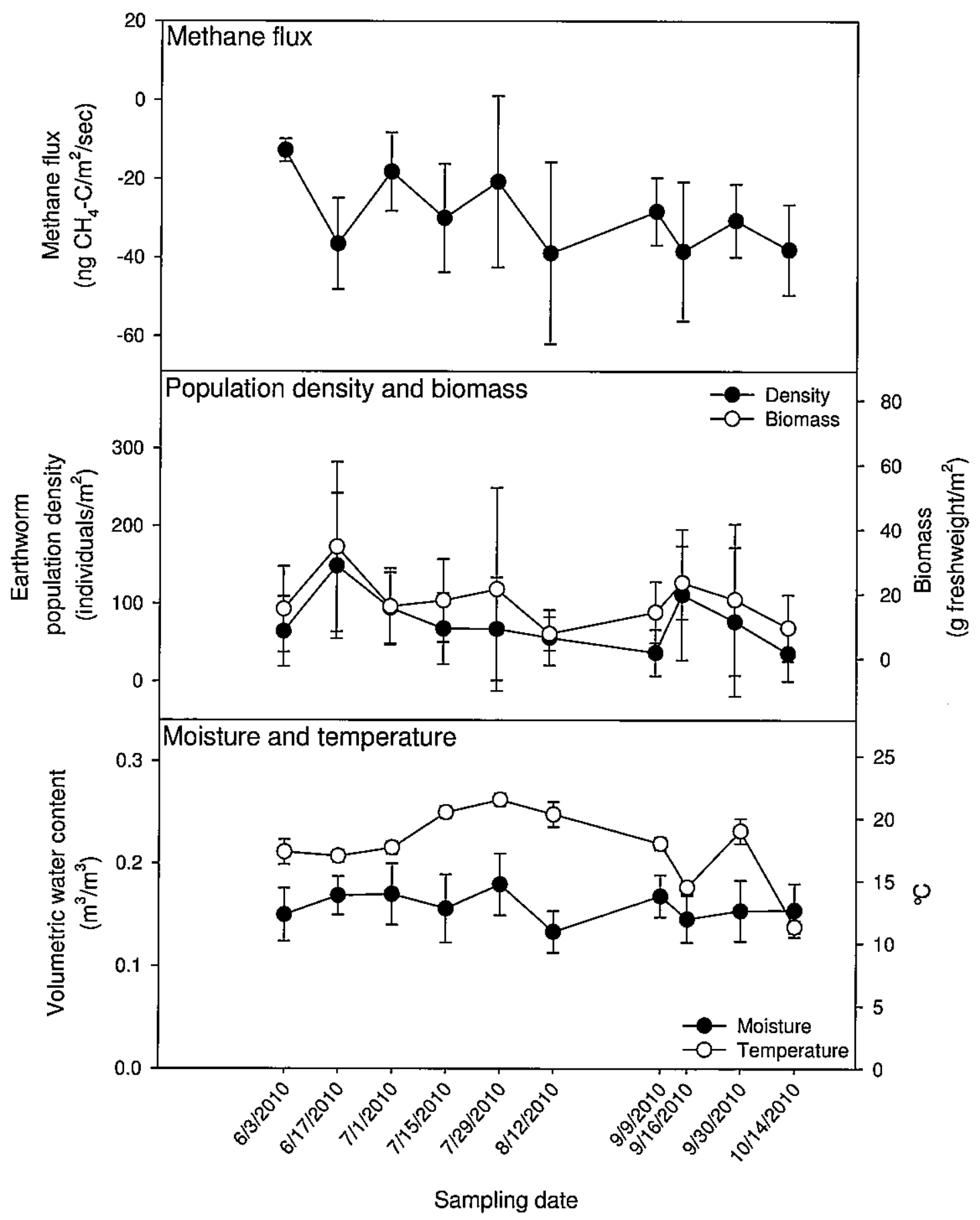


found species at both sites. At PF, other species found include Lumbricus terrestris, Eisenia foetida, and Apporectodea longa. At WAJ, the species found include Lumbricus terrestris, Eisenia foetida, Apporectodea longa, Apporectodea rosea, Eisenia eiseni, and Amynthas spp. Average ( \pm s.d.) individual earthworm mass was similar for both sites over the course of the study, with values of $0.31 \mathrm{~g} \pm 0.06 \mathrm{~g}$ at $\mathrm{PF}$ and $0.25 \mathrm{~g} \pm 0.07 \mathrm{~g}$ at WAJ. No epigeic or endogeic species were found at PF, whereas species from all ecological groups were found at WAJ. The epi-endogeic group was dominant on most sampling days at both sites.

There is little published information on earthworm community composition and dynamics in the northeastern United States. However, our results are consistent with data from other studies in similar ecosystems. For example, earthworm population density was $109 / \mathrm{m}^{2}$, with an average mass of $0.5 \mathrm{~g} / \mathrm{ind}$., in a study by Nordström and Rundgren (1974) in an old pasture in Sweden. Earthworm population density ranged from $5-100 / \mathrm{m}^{2}$, with an average mass of $0.20 \mathrm{~g} / \mathrm{ind}$. in an arable soil in Romania (Gruia, 1969).

The majority of earthworm hatchings are generally in the spring, once the soil warms. Therefore, I would expect that average earthworm mass and proportion of adult to juvenile earthworms to have increased over the course of the study period. However, no trend in individual earthworm mass (Fig. 10 and 11) over time was observed, and neither site showed a trend of decreasing proportion of adults to juveniles during the experimental period (Fig. 8 and 9).

$\mathbf{N H}_{4}$ and $\mathbf{N O}_{3}$. Earthworms secrete mucus with high levels of $\mathrm{NH}_{4}$ and $\mathrm{NO}_{3}$ (Parkin and Berry, 1999; Brown et al., 2000). Both $\mathrm{NH}_{4}$ and $\mathrm{NO}_{3}$ have been shown to 
inhibit the ability of some methane-oxidizing bacteria to consume methane (King and Schnell, 1994). Soil $\mathrm{NH}_{4}$ and $\mathrm{NO}_{3}$ levels were measured to determine whether or not levels of these inorganic forms of nitrogen may be related to methane flux.

Soil $\mathrm{NH}_{4}$ and $\mathrm{NO}_{3}$ levels were similar at both sites, with $\mathrm{NH}_{4}$ levels highest in the spring and early summer, remaining low for the rest of the experimental period (Fig. 12 and 13). At PF, mean ( \pm s.d.), $\mathrm{NH}_{4}$ levels ( $\mu$ g N/g soil) peaked on 7 July $(11.6 \pm 3.0)$ and on 1 July at WAJ $(7.9 \pm 2.9)$, with values ranging between 0 and 2 at both sites for the remainder of the season. These values are within the range of those reported by Savin et al. (2006) of 1.0 to $20.0 \mu \mathrm{g}$ N/g soil for an old field soil in southern Rhode Island over a growing season.

Mean ( \pm s.d.) $\mathrm{NO}_{3}$ levels ( $\mu \mathrm{g} \mathrm{N} / \mathrm{g}$ soil) ranged from 0 to 4.2 soil at $\mathrm{PF}$, with a mean value of $0.6 \pm 1.1$ for the study period. At WAJ, $\mathrm{NO}_{3}$ levels ranged from 0 to 5.5 with a mean value of $0.3 \pm 0.9$ for the study period. These values were also within the range of those reported by Savin et al. (2006), of 2.0 to $8.0 \mu \mathrm{g} \mathrm{NO} 3-\mathrm{N} / \mathrm{g}$ soil.

Organic matter and pH. Soil organic matter (SOM) values were fairly consistent throughout the sampling season at both sites (Fig. 12 and 13), ranging from 19 to $43 \mathrm{~g} / \mathrm{kg}$ at $\mathrm{PF}$ and at 16 to $61 \mathrm{~g} / \mathrm{kg}$ at WAJ. Soil $\mathrm{pH}$ was also consistent throughout the study (Fig. 12 and 13). There were no clear temporal trend in pH throughout the season at either site. At PF, $\mathrm{pH}$ values ranged from 4.9 to 5.6, whereas at WAJ they ranged from 4.8 to 6.1 . 
Figure 12. Levels of soil $\mathrm{NO}_{3}, \mathrm{NH}_{4}$, organic matter, and $\mathrm{pH}$ in supplementary plots $(n=7)$ at Peckham Farm. Bars represent one standard deviation.

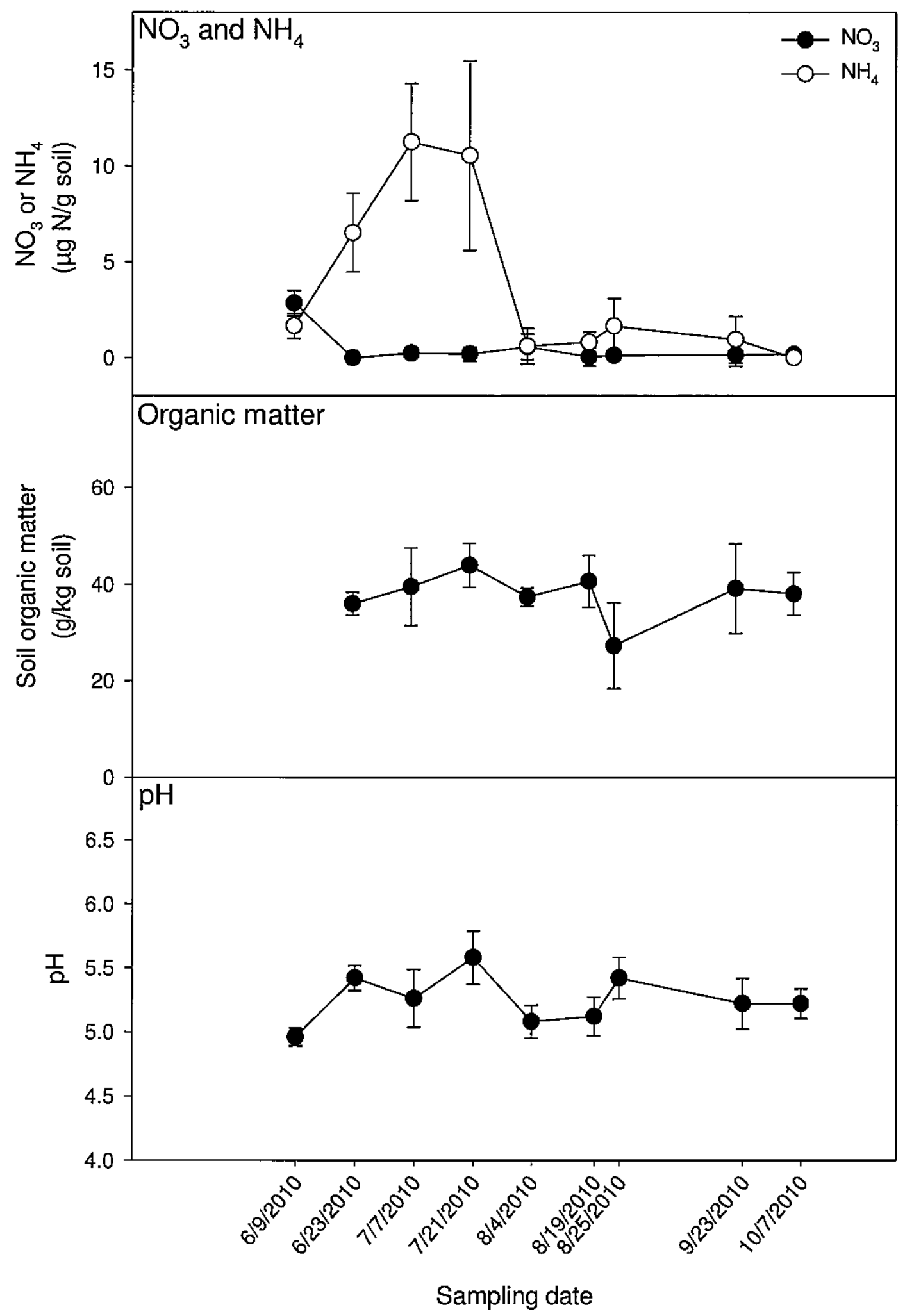


Figure 13. Levels of soil $\mathrm{NO}_{3}, \mathrm{NH}_{4}$, organic matter, and $\mathrm{pH}$ in the supplementary plots $(n=7)$ at W. Alton Jones. Bars represent one standard deviation.

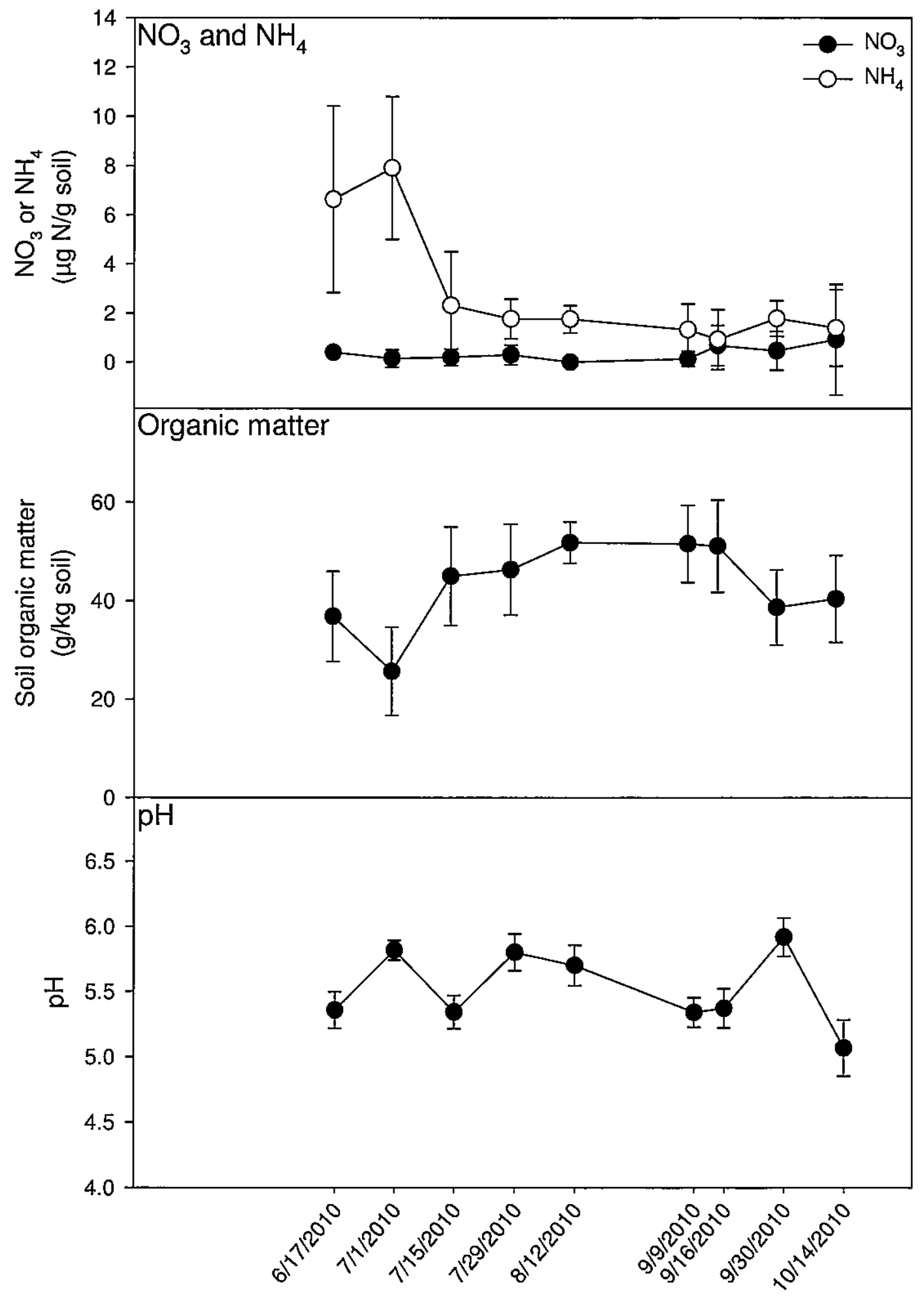

Sampling date 
Methane flux. The magnitude of methane flux in the supplemental plots was similar to that in the manipulated plots (Fig. 2, 3, 10, and 11). In the supplemental plots, mean ( \pm s.d.) methane flux ( $\mathrm{ng} \mathrm{CH}_{4}-\mathrm{C} / \mathrm{m}^{2} / \mathrm{sec}$ ) ranged from $-80 \pm 15$ to $-17 \pm 4$ at $\mathrm{PF}$ and $-40 \pm 18$ to $-14 \pm 3$ at WAJ. Flux values in the undisturbed (U) treatment in the manipulated plots ranged from $-98 \pm 6$ to $-20 \pm 9 \mathrm{ng} \mathrm{CH}_{4}-\mathrm{C} / \mathrm{m}^{2} / \mathrm{sec}$ at $\mathrm{PF}$ and $-42 \pm$ 7 to $2 \pm 5$ at WAJ.

I used a backward-elimination stepwise multiple regression analysis to analyze methane flux as a function of earthworm count and all measured soil properties moisture, temperature, $\mathrm{pH}, \mathrm{O} . \mathrm{M}$. content, $\mathrm{NH}_{4}, \mathrm{NO}_{3}$, and sampling date - to determine whether any of these variables influenced methane flux. I then repeated this analysis using other earthworm parameters besides earthworm count - mass, ecological group, and life stage (juvenile or adult). Results showed no significant relationship between methane flux and any earthworm parameter for either site (Tables 8 and 9). At PF, $\mathrm{NH}_{4}$, moisture, temperature, and date all had a significant correlation with methane flux (Table 8). All of these properties are expected to have an effect on methane flux (Conrad and Wetter, 1990; King and Schnell, 1994; van den Pol-van Dasselaar et al., 1998). By contrast, at WAJ, soil moisture was the only property that had a significant 
Table 8. Results of a stepwise multiple regression analysis with backward elimination ( $\mathrm{P}=0.05$ to eliminate) used to identify earthworm variables or soil properties that affect methane flux within the supplemental plots at Peckham Farm.

$\mathrm{P}$-values reported with significant results $(\mathrm{P} \leq 0.05)$ shown in bold.

\begin{tabular}{|c|c|c|c|c|c|c|c|}
\hline \multirow[b]{2}{*}{$\begin{array}{c}\text { Predictors } \\
\left(\mathrm{R}^{2}\right) \\
\end{array}$} & \multicolumn{7}{|c|}{ Earthworm Variable } \\
\hline & $\begin{array}{l}\text { Count } \\
(0.442) \\
\end{array}$ & $(0.464)$ & $\begin{array}{c}\begin{array}{c}\text { Epigeic } \\
\text { count }\end{array} \\
(0.426) \\
\end{array}$ & $\begin{array}{c}\text { Epi- } \\
\text { endogeic } \\
\text { count } \\
(0.417) \\
\end{array}$ & $\begin{array}{l}\begin{array}{l}\text { Anecic } \\
\text { count }\end{array} \\
(0.420) \\
\end{array}$ & $\begin{array}{c}\begin{array}{c}\text { Juvenile } \\
\text { count }\end{array} \\
(0.445) \\
\end{array}$ & $\begin{array}{l}\text { AduIt } \\
\text { count } \\
(0.417) \\
\end{array}$ \\
\hline $\begin{array}{l}\text { Earthworm } \\
\text { parameter }\end{array}$ & 0.188 & 0.068 & 0.188 & 0.188 & 0.188 & 0.188 & 0.188 \\
\hline $\mathrm{NH}_{4}$ & 0.002 & 0.003 & 0.002 & 0.001 & 0.002 & $/ 0.002$ & 0.002 \\
\hline $\mathrm{NO}_{3}$ & $-^{a}$ & - & - & - & - & - & - \\
\hline $\mathrm{pH}$ & - & - & - & - & - & - & - \\
\hline O.M. & - & - & - & - & - & - & - \\
\hline Moisture & 0.001 & 0.001 & 0.001 & 0.001 & 0.002 & 0.001 & 0.001 \\
\hline Temperature & 0.001 & 0.001 & 0.001 & 0.001 & 0.001 & 0.001 & 0.001 \\
\hline Date & 0.010 & 0.007 & 0.016 & 0.016 & 0.018 & 0.009 & 0.016 \\
\hline
\end{tabular}

${ }^{a}$ Predictors removed from the model because they were not significant $(P>0.05)$. 
Table 9. Results of a stepwise multiple regression analysis with backward elimination $(\mathrm{P}=0.05$ to eliminate) used to identify earthworm variables or soil properties that affect methane flux within the supplemental plots at $\mathrm{W}$. Alton Jones. P-values reported with significant results $(\mathrm{P} \leq 0.05)$ shown in bold.

\begin{tabular}{|c|c|c|c|c|c|c|c|c|}
\hline \multirow[b]{2}{*}{$\begin{array}{c}\text { Predictors } \\
\left(\mathbf{R}^{\mathbf{2}}\right) \\
\end{array}$} & \multicolumn{8}{|c|}{ Earthworm Variable } \\
\hline & $\begin{array}{l}\text { Count } \\
(0.142) \\
\end{array}$ & $\begin{array}{r}\text { Mass } \\
(\mathbf{0 . 1 3 6 )} \\
\end{array}$ & $\begin{array}{l}\begin{array}{l}\text { Epigeic } \\
\text { count }\end{array} \\
(0.145) \\
\end{array}$ & $\begin{array}{c}\text { Epi- } \\
\text { endogeic } \\
\text { count } \\
(0.143) \\
\end{array}$ & $\begin{array}{c}\begin{array}{c}\text { Endogeic } \\
\text { count }\end{array} \\
(0.137) \\
\end{array}$ & $\begin{array}{l}\begin{array}{l}\text { Anecic } \\
\text { count }\end{array} \\
(0.137) \\
\end{array}$ & $\begin{array}{c}\begin{array}{c}\text { Juvenile } \\
\text { count }\end{array} \\
(0.152) \\
\end{array}$ & $\begin{array}{l}\text { Adult } \\
\text { count } \\
\\
(0.140) \\
\end{array}$ \\
\hline $\begin{array}{l}\text { Earthworm } \\
\text { parameter }\end{array}$ & 0.542 & 0.987 & 0.579 & 0.512 & 0.512 & 0.188 & 0.188 & 0.188 \\
\hline $\mathrm{NH}_{4}$ & $-^{a}$ & - & - & - & - & - & - & - \\
\hline $\mathrm{NO}_{3}$ & - & - & - & - & - & - & - & - \\
\hline $\mathrm{pH}$ & - & - & - & - & - & - & - & - \\
\hline O.M. & - & - & - & - & - & - & - & - \\
\hline Moisture & 0.029 & 0.026 & 0.022 & 0.026 & 0.025 & 0.025 & 0.035 & 0.027 \\
\hline Temperature & - & - & - & - & - & - & - & - \\
\hline Date & - & - & - & - & - & - & - & - \\
\hline
\end{tabular}

${ }^{a}$ Predictors removed from the model because they were not significant $(P>0.05)$. 
correlation with methane flux (Table 9). Saturated soils provide conditions for anaerobic areas to develop where methanogenesis can occur, therefore soil moisture is expected to affect methane flux. In drier soils there are more aerobic areas where methane oxidation can occur (van den Pol-van Dasselaar et al., 1998). Our results suggest that the variables that control methane flux at PF differ from those at WAJ. It may be that the microbial communities responsible for methane production and consumption at WAJ are controlled primarily by soil moisture, whereas, the microbial communities at $\mathrm{PF}$ are controlled by soil moisture as well as $\mathrm{NH}_{4}$ and soil temperature.

Higher earthworm population density appears to have the effect of decreasing net soil methane consumption at W. Alton Jones in the manipulated plots (Fig. 3), but population density was not related to methane flux in the supplemental plots. Most of the dates the supplemental measurements were conducted at WAJ were days that no significant differences in methane flux between treatments were found in the supplemental plots. Only two of the dates that the supplemental plot experiment measurements were conducted at WAJ were days that significant differences in methane flux were found between treatments in the supplemental plots. This difference in results may be due to a difference in methodology. It is possible that the insertion of the gas collecting chambers $30 \mathrm{~min}$ prior to gas sampling had some effect on methane flux.

\section{Microcosm Experiments}

Methane flux values measured in the manipulated and supplemental plots represent the net difference between methane production and methane consumption 
rates. To study the effect of earthworms on methane production (acetoclastic and hydrogenotrophic methanogenesis) and methane oxidation processes, I constructed soil mesocosms to collect samples of cast, burrow, bulk soil from soils inoculated with two earthworm species, and a control soil from both sites, to be tested for methane production and methane oxidation. Three mesocosms were constructed for each site by taking soil and inoculating with anecic earthworms, epi-endogeic earthworms, or no earthworms (control). After an incubation period of approximately 90 days, I collected samples of cast, burrow, and bulk soil from the anecic earthworm mesocosm, burrow and bulk soil from the epi-endogeic earthworm mesocosm, and bulk soil from the control mesocosm to measure potential rates of each of these processes for each site.

Methane oxidation. Methane oxidation rate peaked at $62 \mathrm{~h}$ for PF samples and $64 \mathrm{~h}$ for WAJ samples for all treatments (Fig. 14). Peak methane oxidation rates $\left(\mu \mathrm{g} \mathrm{CH}_{4^{-}}\right.$ $\mathrm{C} / \mathrm{g}$ soil/sec; mean \pm s.d.) ranged from $4.1 \pm 0.3$ to $9.5 \pm 1.8$ at $\mathrm{PF}$ and from $4.6 \pm 1.0$ to $9.4 \pm 0.6$ at WAJ. A one-way ANOVA and Holm-Sidak all-pairwise comparison showed that the anecic-cast treatment had a significantly lower methane oxidation rate than all other treatments at both sites for $80 \%$ of the sampling events. All other treatments were similar to each other, with the exception of the epi-endogeic burrow soil which, at WAJ, had a significantly higher methane oxidation rate than all other treatments at all sampling times (except at $62 \mathrm{~h}$ ). 
Figure 14. Mean methane oxidation rates for bulk, burrow, or cast soils from mesocosms containing no earthworms (control), epi-endogeic (epi-endo), or anecic earthworms from Peckham Farm or W. Alton Jones. Bars represent one standard deviation.

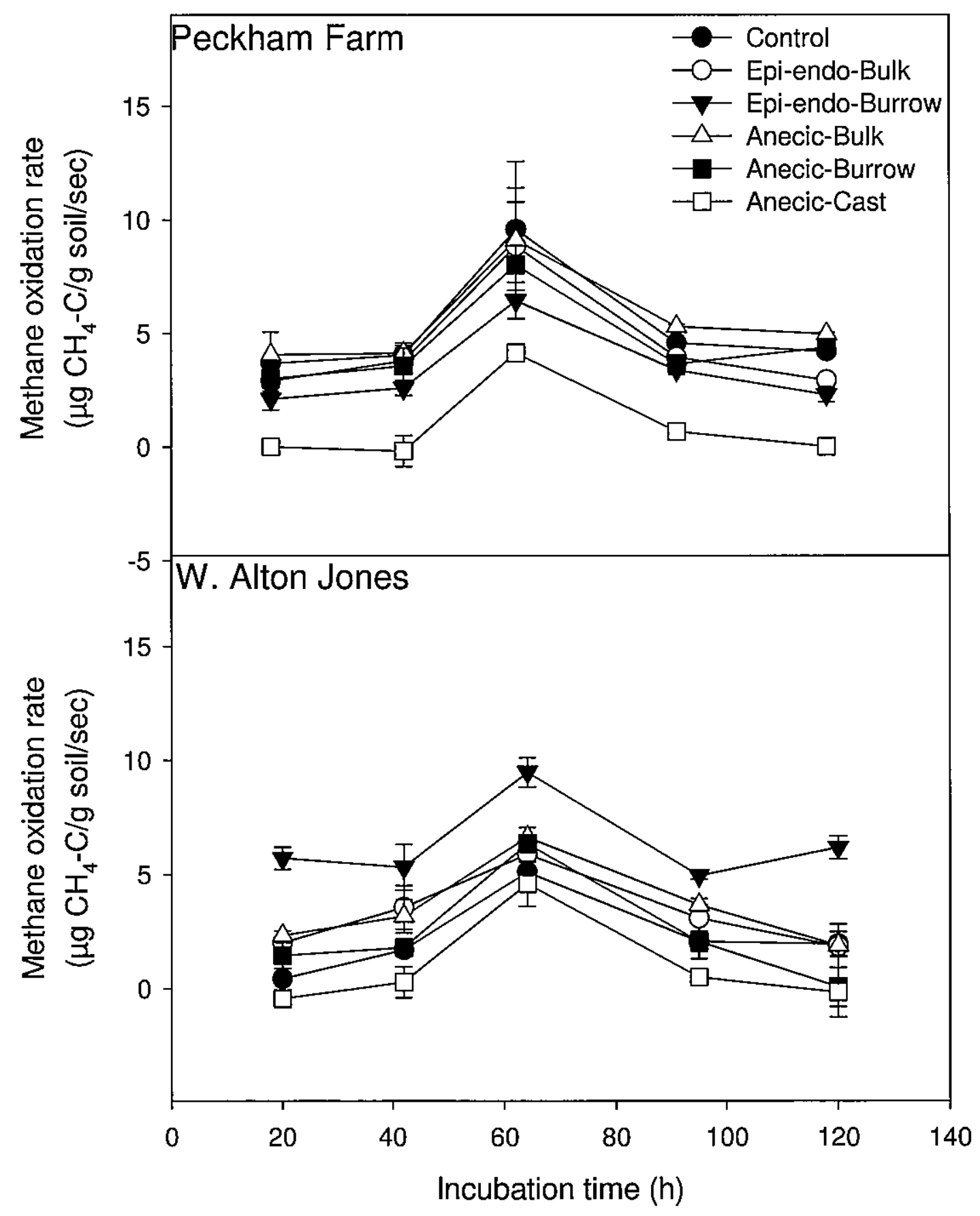


Nitrate and ammonium levels at the end of the experiment were similar for all treatments for soil from both sites, with the exception of the anecic cast soil, which had significantly higher levels of nitrate and ammonium than all other treatments (Fig. 14 and 15$)$. Mean ( \pm s.d.) extractable soil nitrate $\left(\mu \mathrm{g} \mathrm{NO}_{3}-\mathrm{N} / \mathrm{g}\right.$ soil) in the anecic casts was $1,893 \pm 342$ soil for PF and 5,069 \pm 484 for WAJ. Nitrate values for the other treatments ranged from $17.9 \pm 1.9$ to $25.2 \pm 0.6$ for the PF soil and from $8.9 \pm 0.2$ to $169.78 \pm 128.8$ for the WAJ soil. Values of extractable ammonium $(\mu \mathrm{g} \mathrm{NH} 4-\mathrm{N} / \mathrm{g}$ soil $)$ in the anecic cast soil were $12.7 \pm 1.6$ for the PF soil and $193 \pm 24$ for the WAJ soil. Ammonium values for the other treatments ranged from 0 to $1.9 \pm 3.2$ for the PF soil and 0 to $1.5 \pm 3.2$ for the WAJ soil. Except for the anecic cast soil, all other values are similar to that of those found by Parkin and Berry (1994) who found nitrate levels in cast soil to be $80-100 \mu \mathrm{g} \mathrm{NH}_{4}-\mathrm{N} / \mathrm{g}$ soil.

The anecic cast soils at both sites had the lowest rates of methane oxidation, suggesting that anecic earthworms have the potential to decrease net methane consumption in cast soil by reducing oxidation rates. Anecic cast soil also had the highest levels of extractable $\mathrm{NO}_{3}$ and $\mathrm{NH}_{4}$. This suggests an inhibitory effect of the $\mathrm{NO}_{3}$ and/or $\mathrm{NH}_{4}$ on methane oxidation, which has been reported previously (Hütsch, 1998; Steudler et al., 1989). Casts are found on the surface of soil and are deposited by anecic earthworms. Koschorreck and Conrad (1993) found that most of the methane oxidizing activity was in the first few centimeters of an Ap horizon. Thus, 
Figure 15. Mean ( $n=3)$ soil nitrate and ammonium levels at the end of the methane oxidation experiment for soils from Peckham Farm and W. Alton Jones. Bars represent one standard deviation.

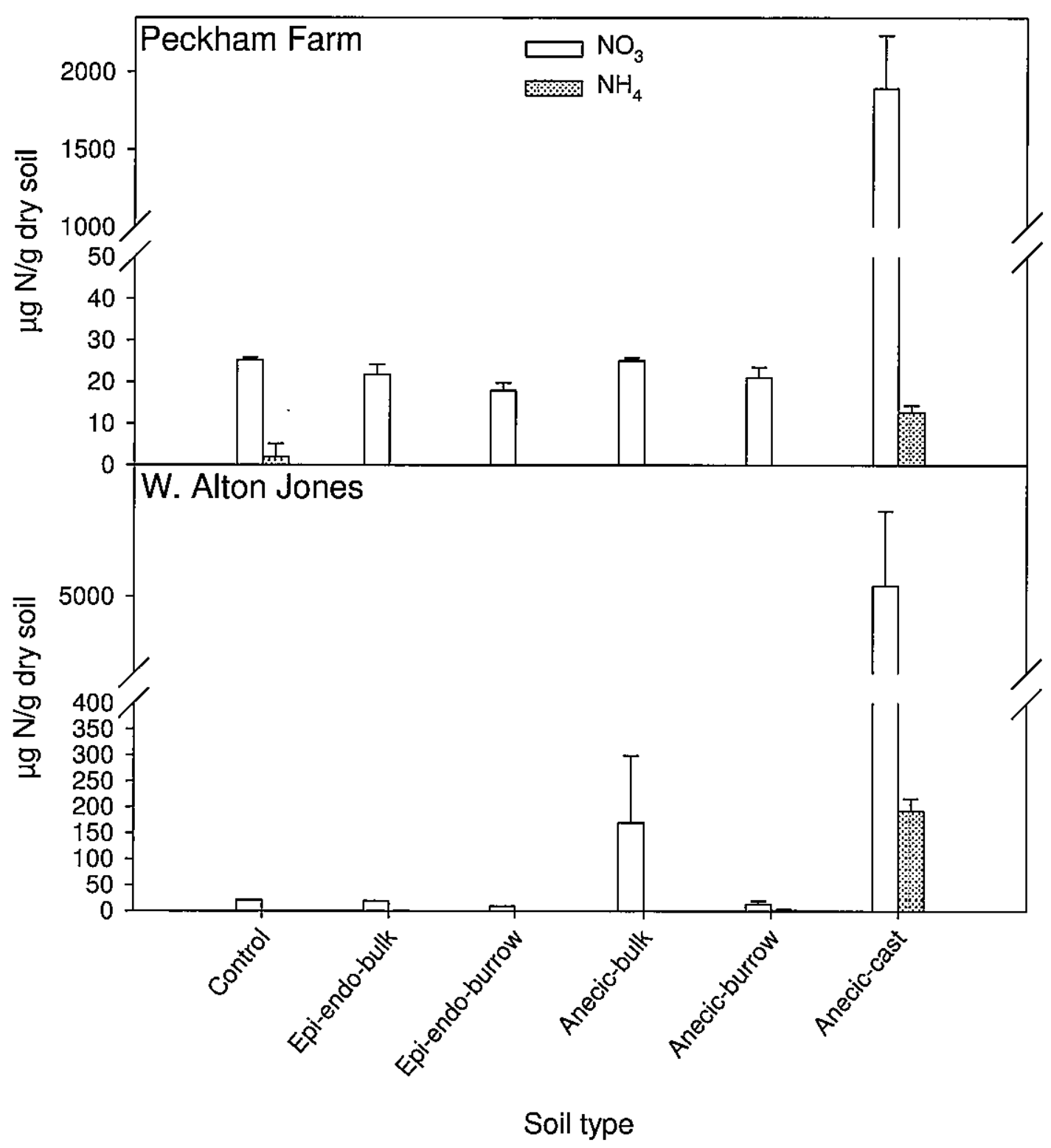


cast deposition on the soil surface could be an important driver of changes in methane flux caused by earthworms.

Hydrogenotrophic methanogenesis. Potential rates of hydrogenotrophic methanogenesis were highest at $68 \mathrm{~h}$ in PF soil and $71 \mathrm{~h}$ in WAJ soil (Fig. 16). Maximum methanogenesis rates $\left(\mu \mathrm{g} \mathrm{C}-\mathrm{CH}_{4} / \mathrm{sec} / \mathrm{g}\right.$ soil) ranged from $0.6 \pm 0.4$ to $2.3 \pm$ 1.3 in the PF soil and $0.6 \pm 0.4$ to $3.1 \pm 1.5$ in the WAJ soil. Results of a two-way ANOVA showed that there were no significant differences in rates of hydrogenotrophic methanogenesis among treatments at any time $(\mathrm{p}>0.05)$ in the $\mathrm{PF}$ soil or WAJ soil, except at $71 \mathrm{~h}$, when the epi-endogeic bulk soil had significantly higher rates of methanogenesis than the epi-endogeic burrow soil, the anecic burrow soil, and the anecic cast soil at PF only.

In the PF soil, mean ( \pm s.d.) extractable soil nitrate $\left(\mu \mathrm{g} \mathrm{NO}_{3}-\mathrm{N} / \mathrm{g}\right.$ soil) in the anecic casts at the end of the experiment was $2,111 \pm 206$ and in the WAJ soil, 5,141 \pm 117 (Fig. 17). Nitrate values for the other treatments ranged from 0 to $11.5 \pm 6.0$ in the PF soil and from $0.08 \pm 0.1$ to $5.4 \pm 7.3$ in the WAJ soil. Values of extractable ammonium in the anecic cast soil were $35.0 \pm 4.1$ in the PF soil and $299 \pm 16$ in the WAJ soil. Ammonium values for the other treatments ranged from $18.6 \pm 3.0$ to $24.9 \pm$ 5.5 in the PF soil and $24.2 \pm 13.0$ to $60.7 \pm 3.0$ in the WAJ soil. It is likely that, as expected, nitrate levels were high in the cast soil prior to incubation. The nitrate was probably not denitrified because of the lack of available carbon. 
Figure 16. Mean ( $n=3)$ hydrogenotrophic methanogenesis rates for bulk, burrow, or cast soils from mesocosms containing no earthworms (control), epi-endogeic (epiendo), or anecic earthworms from Peckham Farm or W. Alton Jones soils. Bars represent one standard deviation.

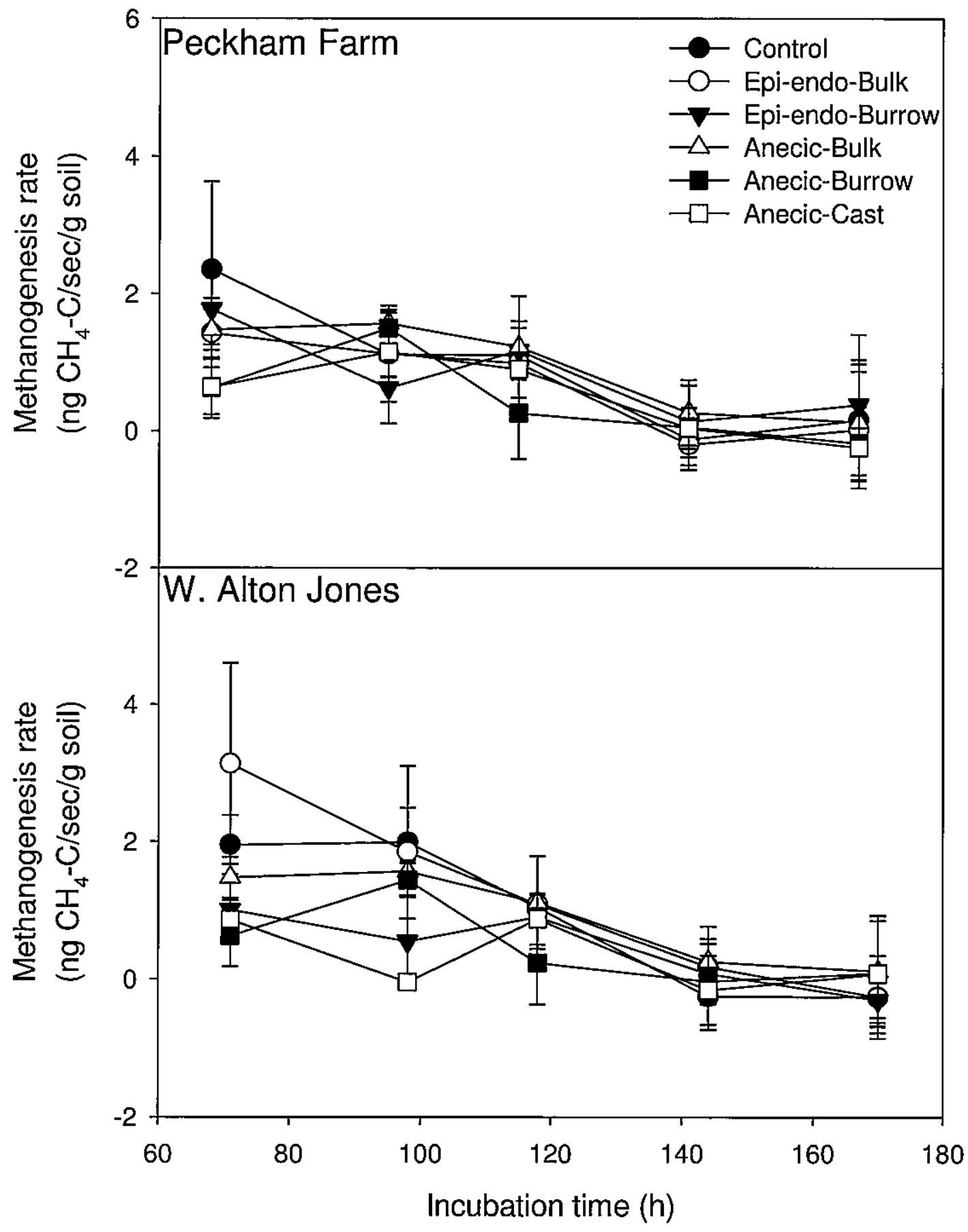


Figure 17. Mean $(n=3)$ nitrate and ammonium levels from bulk, burrow, or cast soils from mesocosms containing no earthworms (control), epi-endogeic (epi-endo), or anecic earthworms following a hydrogenotrophic methanogenesis assay for soils from Peckham Farm and W. Alton Jones. Bars represent one standard deviation.

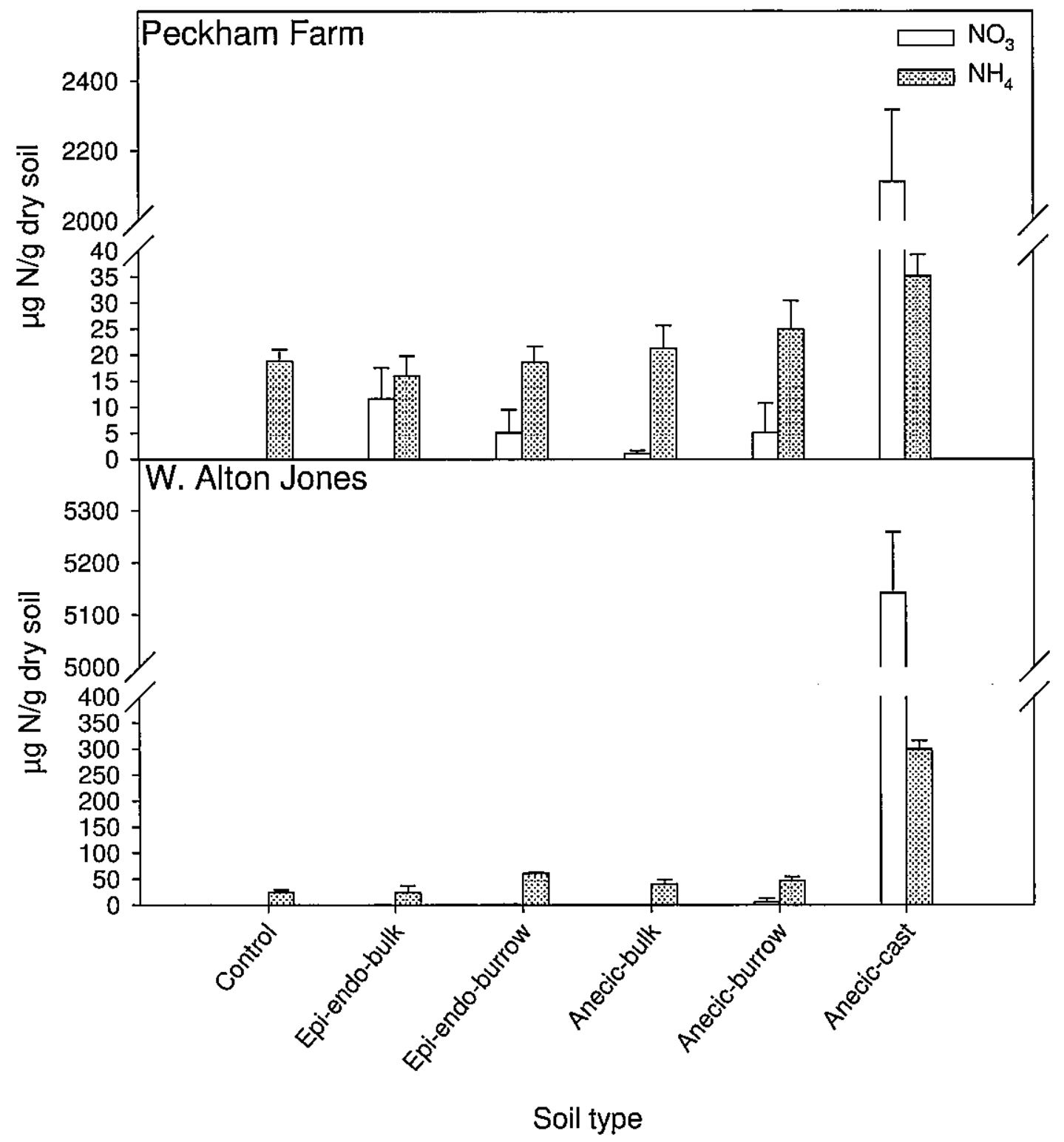


Acetoclastic methanogenesis. A two-way ANOVA showed no significant differences in rates of acetoclastic methanogenesis among treatments at any time for the PF soil. Mean rates of methanogenesis ranged from 0 to $16.0 \pm 10.7 \mu \mathrm{g} \mathrm{CH}_{4^{-}}$ C/sec/g soil (Fig. 18). There was no apparent trend in the rate of methanogenesis over time. By contrast, there were significant differences in the rate of acetoclastic methanogenesis in WAJ soil at $115 \mathrm{~h}$ and $144 \mathrm{~h}$ (Fig. 18). At $115 \mathrm{~h}$, the epi-endogeic burrow treatment had significantly higher rates of methanogenesis than the control, the epi-endogeic bulk treatment, the anecic burrow treatment, and the anecic cast treatment. At $144 \mathrm{~h}$, the epi-endogeic burrow treatment also had significantly higher rates of methanogenesis than the control, the epi-endogeic bulk treatment, and the anecic burrow treatment.

At the end of the experiment there was no detectable soil nitrate in any treatment for either site. It is likely that in this assay, nitrate was denitrified since an available carbon source was introduced in the form of acetate which was not added in the hydrogenotrophic assay. Results of a two-way ANOVA showed that in the PF soil ammonium levels in the anecic cast treatment were higher than all other treatments (Fig. 19). In the WAJ soil, the anecic cast treatment had significantly higher ammonium levels than the anecic burrow and the epi-endogeic burrow. Values of extractable ammonium in the anecic cast soil were $188.2 \pm 9.7$ in the PF soil and 62.5 \pm 4.0 in the $\mathrm{WAJ}$ soil. Ammonium values for the other treatments ranged from 21.6 \pm 1.1 to $92.0 \pm 3.2$ in the PF soil and $11.2 \pm 8.2$ to $30.1 \pm 17.2$ in the WAJ soil. 
Figure 18. Mean $(n=3)$ acetoclastic methanogenesis rates for bulk, burrow, or cast soils from mesocosms containing no earthworms (control), epi-endogeic (epi-endo), or anecic earthworms from Peckham Farm or W. Alton Jones soils. Bars represent one standard deviation.

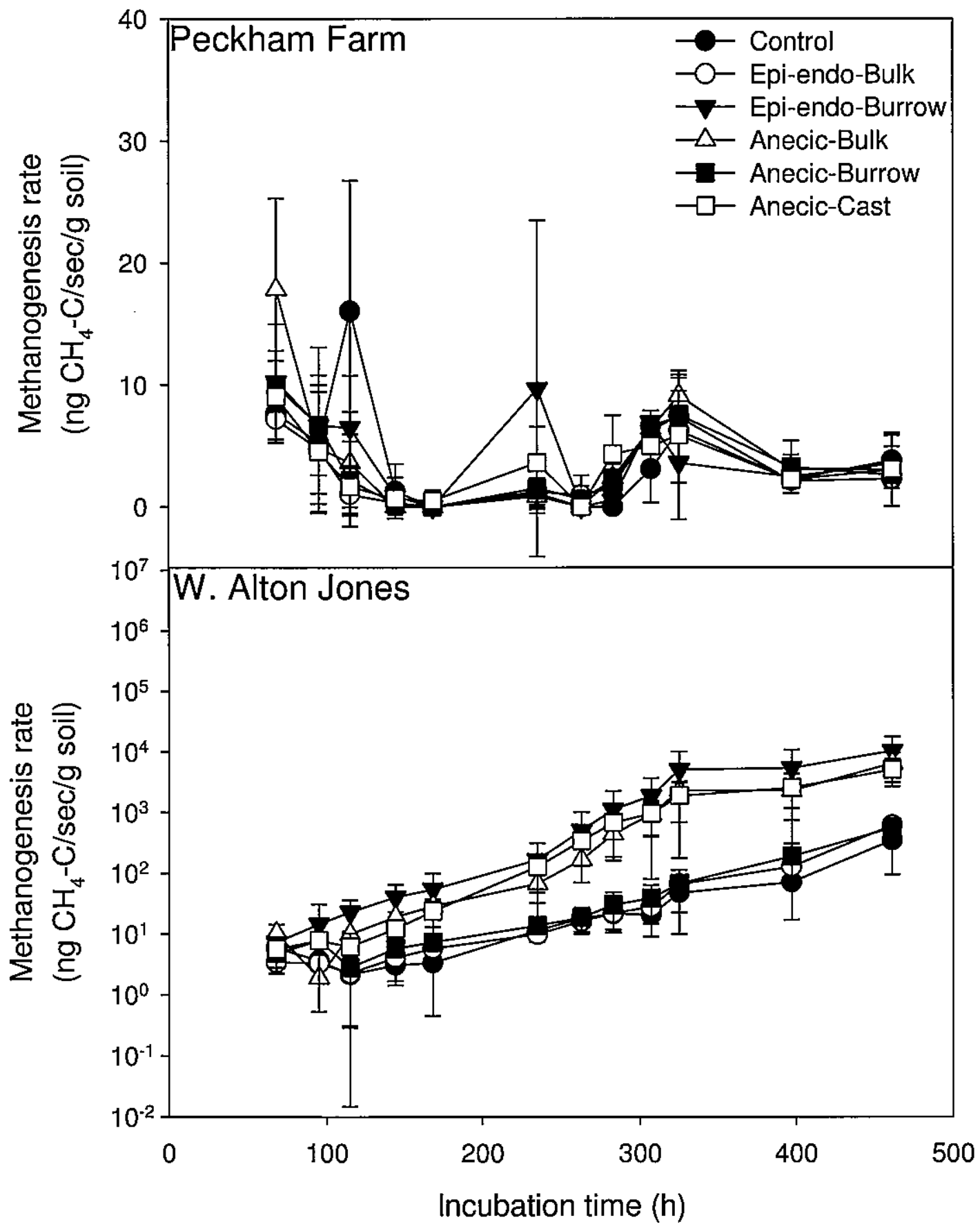


Figure 19. Mean $(n=3)$ ammonium levels from bulk, burrow, or cast soils from mesocosms containing no earthworms (control), epi-endogeic (epi-endo), or anecic earthworms following an acetoclastic methanogenesis assay for soils from Peckham Farm and W. Alton Jones. Bars represent one standard deviation. Nitrate was below detectable limit for all treatments at both sites.

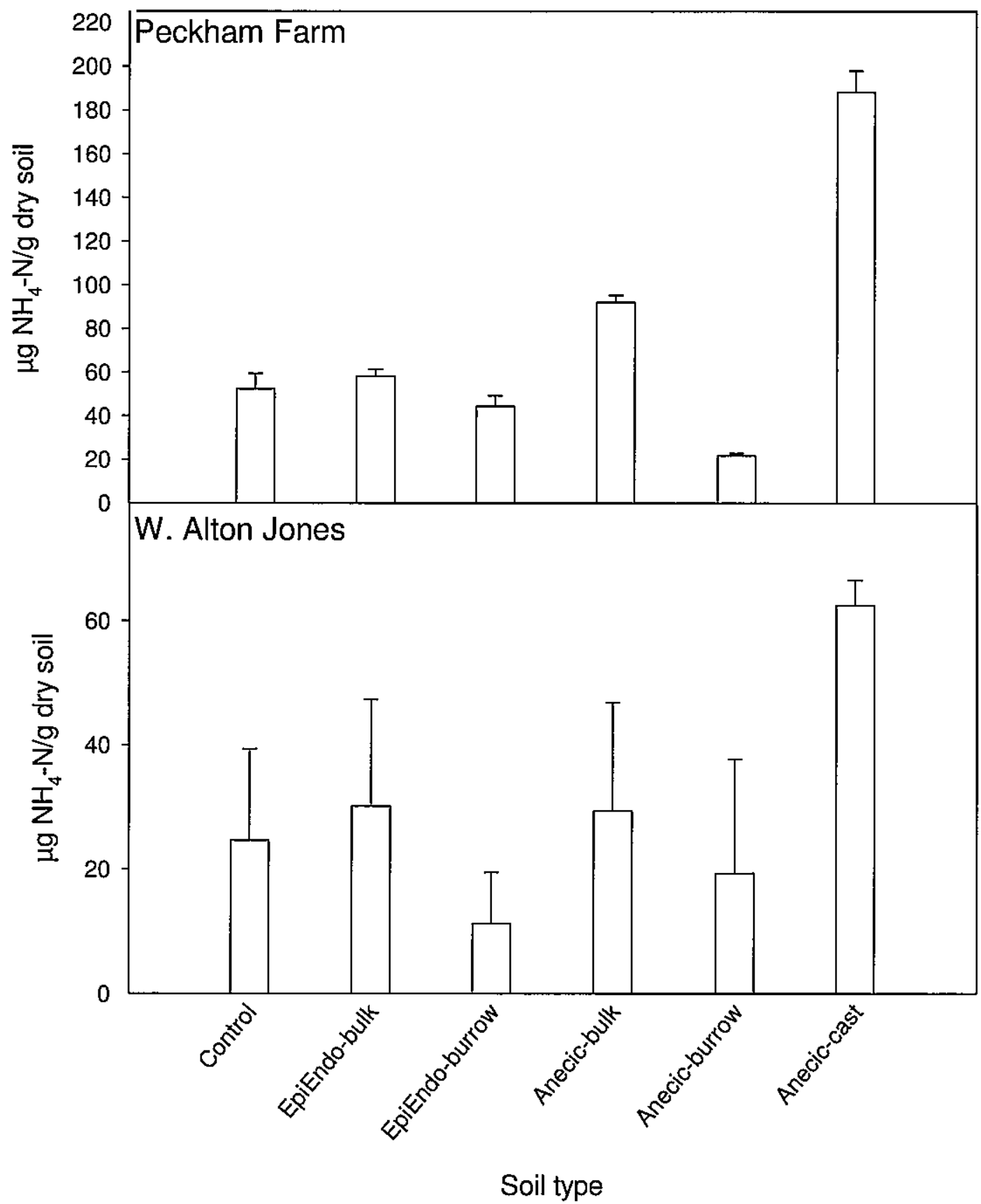


Results of these assays may provide some insight into the mechanisms behind the differences in methane flux found in the manipulated plots experiment. On multiple days at both sites in the manipulated plots experiment there were effects of earthworms, lowering net methane consumption (Fig. 2 and 3). Measurements of potential methane oxidation rates showed that anecic-cast treatments had significantly lower methane oxidation $(\mathrm{p}<0.05)$ than all other treatments for both sites on $80 \%$ of the time (Fig. 14). This suggests that soils with higher earthworm population densities, specifically anecic earthworms, would presumably have more earthworm casts, which may lower methane oxidation potential. In addition, in the manipulated plots experiment the majority of the flux differences were found at the W. Alton Jones site. In the acetoclastic methanogenesis assay, the W. Alton Jones soil showed higher rates of methanogenesis in the epi-endogeic burrow, anecic bulk, and anecic cast treatments, suggesting that earthworm activity provides an augmented response to anaerobic conditions in relation to acetoclastic methanogenesis, particularly cast soil. Anecic cast soil also exhibited a trend of higher levels of inorganic nitrogen than other soil treatments, particularly in the hydrogenotrophic methanogenesis assay. Ammonium can inhibit methane oxidation by outcompeting methane for the active binding sites on methane monooxygenase, resulting in less methane consumption (Bedard and Knowles, 1989). 


\section{CONCLUSION}

The results of my field experiments suggest that earthworms have a limited effect on methane flux in soil. In the manipulated plots experiment, the effect was primarily observed at WAJ, suggesting that other variables may need to be considered to understand the reason for this effect, such as microbial community composition. At WAJ, the presence of earthworms decreased net methane consumption in soil on seven dates out of a total of 26 sampling days. By contrast, at PF, the presence of earthworms decreased net methane consumption in soil on two out of a total 27 sampling days, yet increased net methane consumption on three out of 27 sampling dates.

The data from the supplemental plots did not show a significant relation between any earthworm parameter and methane flux. The data did show methane flux to be dependent on inorganic nitrogen, soil moisture, and temperature as expected. It is possible that the more important factor in the effect of earthworms on methane flux is the existence of burrows in the soil, not just the presence of earthworms. Since the sampled areas in the supplemental plot experiment were not fenced off for a long period of time, as they were in the manipulated plots experiment, the earthworm population density data may not have been related to burrow count and internal surface area. There may have been earthworm activity prior to the insertion of the chamber that contributed to the effects on methane flux through burrowing; however; if the earthworms were no longer in that area, earthworm population density would not be representative of the number of burrows in soil. 
The results of assays to determine potential rates of methane oxidation and methanogenesis rates of soil from each site suggests that the soil from WAJ has a higherpotential to contribute greatly to acetoclastic methanogenesis in epi-endogeic burrow, anecic bulk, and anecic cast soil. There was a continued trend of higher rates of methanogenesis in the epi-endogeic burrow, anecic bulk, and anecic cast treatments which was not observed in the PF soil. This may explain why differences in flux were observed more frequently at WAJ in the manipulated plot experiment. The effect of earthworms on methane flux may be more or less pronounced depending on the existing microbial community composition in the soil. The resident communities of acetoclastic methanogens at WAJ may be able to react faster to changes in soil conditions. It is also possible that hydrogenotrophic methanogens are not as responsive to the effects of earthworms on soil properties.

My results show that earthworms have the potential to lower net consumption of methane in pasture soil, specifically by decreasing methane oxidation and increasing acetoclastic methanogenesis at WAJ. At PF, there is evidence that earthworms decrease methane oxidation but do not affect either methanogenic process. More research is needed to understand the complex interactions between earthworms and the soil environment, specifically to determine the effect of earthworms on methanogenesis. Future research should incorporate microbial community analysis of the organisms involved in methane production and consumption in order to better understand these interactions. 


\section{REFERENCES}

Amador, J.A., and J.H. Görres. 2005. Fauna, p. 181-200, In D. M. Sylvia, et al., eds. Principles and Applications of Soil Microbiology, 2nd ed. Pearson-Prentice Hall, Upper Saddle River, NJ.

Bedard, C., and R. Knowles. 1989. Physiology, biochemistry, and specific inhibitors of $\mathrm{CH}_{4}, \mathrm{NH}_{4}^{+}$, and $\mathrm{CO}$ oxidation by methanotrophs and nitrifiers.

Microbiology and Molecular Biological Review 53:68-84.

Blaire, J.M., R.W. Parmalee, and P. Lavelle. 1995. Influence of earthworms on biogeochemistry., p. 127-158, In P. F. Hendrix, ed. Earthworm Ecology and Biogeography in North America. CRC Press, Boca Raton, FL.

Bouché, M.B. 1977. Strategies lombriciennes. Ecological Bulletins:122-132.

Brock, T.D., M.T. Madigan, J.M. Martinko, and J. Parker. 1994. Biology of Microorganisms. 7th ed. Prentice Hall, Englewood Cliffs, NJ.

Brown, G.G., I. Barois, and P. Lavelle. 2000. Regulation of soil organic matter dynamics and microbial activity in the drilosphere and the role of interactions with other edaphic functional domains. European Journal of Soil Biology 36:177-198.

Conrad, R., and B. Wetter. 1990. Influence of temperature on energetics of hydrogen metabolism in homoacetogenic, methanogenic, and other anaerobic bacteria. Archives of Microbiology 155:94-98.

Devliegher, W., and W. Verstraete. 1997. Microorganisms and soil physico-chemical conditions in the drilosphere of Lumbricus terrestris. Soil Biology and Biochemistry 29:1721-1729.

Dunfield, P., and R. Knowles. 1995. Kinetics of inhibition of methane oxidation by nitrate, nitrite, and ammonium in a humisol. Applied Environmental Microbiology 61:3129-3135.

Edwards, C.A. 2004. The importance of earthworms as key representatives of the soil fauna, p. 3-11, In C. A. Edwards, ed. Earthworm Ecology., 2nd ed. CRC Press, Boca Raton, FL.

Flessa, H., R. Ruser, P. Dörsch, T. Kamp, M.A. Jimenez, J.C. Munch, and F. Beese. 2002. Integrated evaluation of greenhouse gas emissions $\left(\mathrm{CO}_{2}, \mathrm{CH}_{4}, \mathrm{~N}_{2} \mathrm{O}\right)$ from two farming systems in southern Germany. Agriculture, Ecosystems \& Environment 91:175-189. 
Gruia, L. 1969. Repartition quantitative des lombricides dans les sols de Roumanie. Pedobiologia 9:99-102.

Haines, P.J., and N.C. Uren. 1990. Effects of conservation tillage farming on soil microbial biomass, organic matter and earthworm populations, in north-eastern Victoria, Australia Journal of Experimental Agriculture 30:365-371.

Hale, C. 2007. Earthworms of the Great Lakes. Stensaas and Kollath, Duluth, MN.

Hendrix, P.F., A.V. Tiunov, C.M. Hale, A.R. Holdsworth, and T.S. VsevolodovaPerel. 2006. Invasion patterns of Lumbricidae into the previously earthwormfree areas of northeastern Europe and the western Great Lakes region of North America. Biological Invasions 8:1223-1234

Hendrix, P.F., and P.J. Bohlen. 2002. Exotic earthworm invasions in North America: Ecological and policy implications. BioScience. 52:801-811.

Holmes, A.J., A. Costello, M.E. Lidstrom, and J.C. Murrell. 1995. Evidence that particulate methane monooxygenase and ammonia monooxygenase may be evolutionarily related. FEMS Microbiology Letters 132:203-208.

Hütsch, B.W. 1998. Methane oxidation in arable soil as inhibited by ammonium, nitrite, and organic manure with respect to soil pH. Biology and Fertility of Soils 28:27-35.

Karsten, G.R., and H.L. Drake. 1995. Comparative assessment of the aerobic and anaerobic microfloras of earthworm guts and forest soils. Applied Environmental Microbiology 61:1039-1044.

Keeney, D.R., and D.W. Nelson. 1982. Nitrogen-inorganic forms., p. 643-709, In A. L. Page, et al., eds. Methods of soil analysis. ASA-SSSA, Madison, WI.

King, G.M., and S. Schnell. 1994. Ammonium and nitrite inhibition of methane oxidation by Methylobacter albus BG8 and Methylosinus trichosporium OB3b at low methane concentrations. Applied Environmental Microbiology 60:35083513.

Klok, C., M. Zorn, J.E. Koolhaas, H.J.P. Eijsackers, and C.A.M.v. Gestel. 2006. Does reproductive plasticity in Lumbricus rubellus improve the recovery of populations in frequently inundated river floodplains? Soil Biology and Biochemistry, 38:611-618.

Koch, O., D. Tscherko, and E. Kandeler. 2007. Seasonal and diurnal net methane emissions from organic soils of the eastern alps, austria: Effects of soil 
temperature, water balance, and plant biomass. Arctic, Antarctic, and Alpine Research 39:438-448.

Koschorreck, M., and R. Conrad. 1993. Oxidation of atmospheric methane in soil: Measurements in the field, in soil cores and in soil samples. Global Biogeochemicall Cycles 7:109-121.

Linden, D.R., P.F. Hendrix, D.C. Coleman, and P.C.J. Van Vliet. 1994. Faunal indicators of soil quality, p. 91-106, In J. W. Doran, et al., eds. Defining soil quality for a sustainable environment. SSSA Spec. Publ.

Myrold, D. 2005. Transformations of nitrogen, p. 333-372, In D. M. Sylvia, et al., eds. Principles and Applications of Soil Microbiology, 2nd ed. Pearson-Prentice Hall, Upper Saddle River, NJ.

Nesbit, S.P., and G.A. Breitenbeck. 1992. A laboratory study of factors influencing methane uptake by soils. Agriculture, Ecosystems and Environment 41:39-54.

Nordström, S., and S. Rundgren. 1974. Environmental factors and lumbricid associations in southern Sweden. Pedobiologia 14:1-27.

Norman, J.M., C.J. Kucharik, S.T. Gower, D.D. Baldocchi, P.M. Crill, M. Rayment, K. Savage, and R.G. Striegl. 1997. A comparison of six methods for measuring soil-surface carbon dioxide fluxes. Journal of geophysical research 102:28,771-28,777.

Parkin, T.B., and E.C. Berry. 1999. Microbial nitrogen transformations in earthworm burrows. Soil Biology and Biochemistry 31:1765-1771.

Parmalee, R.W., M.H. Beare, W. Cheng, P.F. Hendrix, S.J. Rider, D.A. Crossley, and D.C. Coleman. 1990. Earthworms and enchytraeids in conventional and notillage agroecosystems: A biocide approach to assess their role in organic matter breakdown. Biology and Fertility of Soils 10:1-10.

Ramaswamy, V., O. Boucher, J. Haigh, D. Hauglustaine, J. Haywood, G. Myhre, T. Nakajima, G. Shi, S. Solomon, R.E. Betts, R. Charlson, C.C. Chuang, J.S. Daniel, A.D. Del Genio, J. Feichter, J. Fuglestvedt, P.M. Forster, S.J. Ghan, A. Jones, J.T. Kiehl, D. Koch, C. Land, J. Lean, U. Lohmann, K. Minschwaner, J.E. Penner, D.L. Roberts, H. Rodhe, G.J. Roelofs, L.D. Rotstayn, T.L. Schneider, U. Schumann, S.E. Schwartz, M.D. Schwartzkopf, K.P. Shine, S.J. Smith, D.S. Stevenson, F. Stordal, I. Tegen, R. van Dorland, Y. Zhang, J. Srinivasan, and F. Joos. 2001. Radiative Forcing of Climate Change Contribution of working group I to the Third Assessment Report of the Intergovernmental Panel on Climate Change, edited by: 30 Houghton, J. T., Ding, Y., Griggs, D. J., Noguer, M., van der Linden, P. J., Dai, X., Maskell, K., and Johnson, C. A., Cambridge Univ. Press, New York, 349-419 
Schimel, J.P., and E.A. Holland. 2005. Global gases, p. 491-509, In D. M. Sylvia, et al., eds. Principles and Applications of Soil Microbiology, 2nd ed. Pearson Prentice Hall, Upper Saddle River, NJ.

Sessitsch, A., A. Weilharter, M.H. Gerzabek, H. Kirchmann, and E. Kandeler. 2001. Microbial population structures in soil particle size fractions of a long-term fertilizer field experiment. Applied Environmental Microbiology 67:42154224.

Sheppard, S.K., A.J. McCarthy, J.P. Loughnane, N.D. Gray, I.M. Head, and D. Lloyd. 2005. The impact of sludge amendment on methanogen community structure in an upland soil. Applied Soil Ecology 28:147-162.

Steudler, P.A., R.D. Bowden, J.M. Melillo, and J.D. Aber. 1989. Influence of nitrogen fertilization on methane uptake in temperate forest soils. Nature 341:314-316.

Trenberth, K.E., P.D. Jones, P. Ambenje, R. Bojariu, D. Easterling, A.K. Tank, D. Parker, F. Rahimzadeh, J.A. Renwick, M. Rusticucci, B. Soden, and P. Zhai. 2007. Observations: surface and atmospheric climate change., p. 235-336., In S. Solomon, et al., eds. Climate change 2007: The Physical Science Basis. Contribution of working Group I to the Fourth Assessment Report of the Intergovernmental Panel on Climate Change. Cambridge University Press, New York, NY.

van den Pol-van Dasselaar, A., M.L. van Beusichem, and O. Oenema. 1998. Effects of soil moisture content and temperature on methane uptake by grasslands on sandy soils. Plant and Soil 204:213-222.

Wagner, C., A. GriessHammer, and H.L. Drake. 1996. Acetogenic capacities and the anaerobic turnover of carbon in a Kansas prairie soil. Applied Environmental Microbiology 62:494-500.

Wust, P.K., M.A. Horn, and H.L. Drake. 2009. In situ hydrogen and nitrous oxide as indicators of concomitant fermentation and denitrification in the alimentary canal of the earthworm Lumbricus terrestris. Applied Environmental Microbiology 75:1852-1859.

Zinder, S.H. 1993. p. 128-150, In J. G. Ferry, ed. Methanogenesis: Ecology, Physiology, Biochemistry, and Genetics. Chapman and Hall, NY. 